\title{
A Glimpse of Sufism from the Circle of Ibn Taymiyya
}

\section{An Edition and Translation of al-Ba'labakkì's (d. 734/1333) Epistle on the Spiritual Way (Risālat al-Sulūk)}

\author{
Arjan Post \\ Utrecht University (The Netherlands) \\ aajpost@gmail.com
}

\begin{abstract}
This article provides yet another testament to the reality that some form of Sufism existed amidst the circle of students and followers of Ibn Taymiyya (d. 728/1328). Based on a unique manuscript from Damascus, presented here for the first time is an Arabic edition and English translation of Risālat al-sulük (Epistle on the Spiritual Way) by al-Balabakkī (d. 734/1333), a Hanbalite student of Ibn Taymiyya who was also trained in the Sufi way. This is preceded by a study that sheds light on al-Balabakkìs intellectual context, which is primarily concerned with the place of Sufism in Ibn Taymiyya's circle. The article then proceeds with a biography of al-Ba'labakkī, followed by some relevant notes on the manuscript of Risālat al-sulūk and its edition and translation.
\end{abstract}

* I would like to thank Dr. Khayr Allāh al-Sharīf, to whom I am greatly indebted for his invaluable help in obtaining pictures of a manuscript of Risālat al-sulük. I also want to express my gratitude to Mr. Mouaz, who helped me get in contact with Dr. al-Sharif. The current article is dedicated to them and the Syrian people. Furthermore, many thanks are due to my supervisor, Prof. Dr. Christian Lange, and to Dr. Amr Ryad for reading the first draft of this article and commenting on it. Last but not least, I am indebted to the Arabic reading group of Utrecht University for providing me with input regarding my translation. Needless to say that any mistakes or inaccuracies are completely my own.

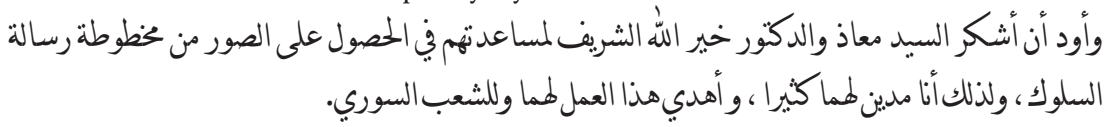

(C) ARJAN POST, 2016 | DOI 10.1163/22105956-12341289

This is an open access article distributed under the terms of the Creative Commons Attribution 4.0 International (CC-BY 4.0) License. http://creativecommons.org/licenses/by/4.0/ 


\section{Keywords}

al-Balabakkī - Damascus - Hanbalism - Ibn Taymiyya - mysticism - speculative theology - Sufism - sulūk - traditionalism - al-Wāsiṭi

\section{Introduction}

As the past years have shown an increasing interest among scholars in the Hanbalite shaykh al-Islām Taqī al-Dīn Aḥmad Ibn Taymiyya (d. 728/1328), there is a slowly growing awareness that the study of the people around him, that is, his circle of followers and students, is also deserving of attention. ${ }^{1}$ When it comes to tașawwuf, or Sufism, I would argue that its presence in Ibn Taymiyya's own intellectual context as a recognized Islamic discipline of spirituality can be understood more deeply by also studying its presence among the members of his circle. ${ }^{2}$ While for some of them it is practically impossible to establish whether they were in any way involved in Sufism, others actually composed works that clearly deal with the subject. An example of the latter category is found in the person of the Hanbalite Zayn al-Dīn 'Abd al-Raḥmān al-Balabakkī, who was both a student of Ibn Taymiyya and a Sufi in the real sense of the word. But unlike Ibn Taymiyya or his most celebrated student, Ibn Qayyim al-Jawziyya (d. 751/1350), al-Ba'labakkī did not leave behind much of a legacy. He neither produced a large oeuvre of writings nor reached any lasting fame as a Muslim scholar. We thus have very limited source-material from which to extract detailed information concerning his life and teachings, in particular when it comes to his views on Sufism.

1 Caterina Bori is a good example of a scholar who has applied this approach. See for instance her article that deals with the collection and edition of Ibn Taymiyya's writings by his students, and to some degree also her article on Ibn Taymiyya's jamāa a, although this is more concerned with his overall position in traditionalist circles. Cf. Caterina Bori, "Ibn Taymiyya wa-Jamācatuhu." In Ibn Taymiyya and his Times, ed. Yossef Rapoport and Shahab Ahmed (Lahore: Oxford University Press, 2010), 23-52, and: "The Collection and Edition of Ibn Taymīyah's Works: Concerns of a Disciple," Mamlūk Studies Review 13 (2009): 47-67. Also, the recent volume edited by her, containing articles that focus on Ibn Qayyim al-Jawziyya: A Scholar in the Shadow: Essays in the Legal and Theological Thought of Ibn Qayyim al-Ğawziyyah, ed. Caterina Bori (Rome: Istituto per l'Oriente, 2010).

2 Mention must be made of a much earlier effort in this particular field by Éric Geoffroy, "Le traité de soufisme d'un disciple d'Ibn Taymiyya: Aḥmad 'Imād al-Dīn al-Wāsițī (m. 711/1311)," Studia Islamica, No. 82 (1995): 83-101. 
It is exactly here where the current article provides a contribution by presenting for the first time an Arabic edition and English translation of al-Ba'labakkì's Risālat al-sulük, likely the sole surviving tract by his hand that deals with the subject of Sufism. In this concise treatise, al-Ba labakkī aims to show that sulūk, the spiritual way towards God, can only be completed by means of two interdependent aspects: piety (taqwā) and renunciation of the material world (zuhd). By the first he means mostly the outer dimension of religion, which requires intimate knowledge of and close adherence to Islamic law; by the second he means mostly the inner dimension of religion, which requires the purification of the heart and abstinence from worldly passions. There is no explicit mention of the words șüfi or tașawwuf, but based on the content and the author's background we can certainly say that we are dealing with a treatise that falls under the category of Sufism. The style of Risālat al-sulūk is sober, with a practical rather than a mystical approach to the spiritual way. While it does contain references to the Sufi concept of annihilation in $\operatorname{God}\left(\right.$ fană $\bar{a}^{3} \grave{\imath}$ Alläh) and to the substitutes $(a b d \bar{a} l)$, an elite class of saints (awliy $\bar{a})$, we must remember that such terminology was firmly embedded in the vocabulary of Sunni Islam in the Mamluk period. ${ }^{3} \mathrm{Al}-\mathrm{Ba}$ labakkīs main purpose in the treatise is to invoke in its reader an awareness of God, which is to inspire action, inwardly and outwardly, in accordance with God's desire, with the ultimate goal to attain a spiritual connection with Him. It could be argued that the importance of the Risāla lies not so much in its contents, since its brevity makes it difficult to make any large assumptions about al-Balabakkì's thought on Sufism. That would indeed require much more material on the subject by his hand, which, as far as I know, is simply not extant anymore. Its true significance lies rather in the fact that it is yet another testament to the reality that some form of Sufism existed in the circle of Ibn Taymiyya.

Below follows a concise study that aims to shed light on several issues that are of relevance to the text of Risālat al-sulük. Firstly, in view of al-Ba'labakkī's identity as both a follower of Ibn Taymiyya and a Sufi, it is in place to provide some background to the intellectual context against which we should read the Risāla. I will do this by demonstrating that there was not only a certain tradition of Sufism that was accepted and respected by Ibn Taymiyya, but that there is even clear evidence that some form of Sufism was actively taught to several members of his circle, an example of whom was al-Balabakkī himself. I thereby

3 While Ibn Taymiyya would later come to denounce the term "abdāl" completely, he still used it in his al-'Aqïda al-wāsițiyya, written in 698/1298-9, cf. Majmū' Fatāwā, ed. 'Abd al-Rahmān b. Muhammad b. Qāsim, 37 vols. (Riyadh: Wizārat al-Shu'ūn al-Islāmiyya wa-l-Awqāf wa-l-Da'wat wa-l-Irshād, 1995), 3:159. He also employs the term fanä in several of his works. 
aim to show what the latter's background in Sufism was, so that we can place his Risāla in a specific tradition. This is followed by a biography of al-Ba labakkī based on the available material I have been able to find. The final section of the introduction will elaborate upon my discovery of the manuscript of Risālat al-sulük and offer a few notes on the process of editing and translating it.

\section{Sufism and Traditionalism}

While Ibn Taymiyya's relationship with Sufism has been the subject of some controversy, having been portrayed as both a staunch opponent of Sufism and an actual sufi himself, the dominant view on this subject is becoming increasingly nuanced, placing him, in a sense, somewhere in the middle of these two extremes. ${ }^{4}$ In a recent contribution, for instance, Ovamir Anjum argues that, without identifying themselves as Sufis, Ibn Taymiyya and Ibn al-Qayyim both "endorsed Sufism devoid of mysticism, and wished to recover the earliest tradition of Sufism when mystical knowledge had not challenged the primacy of scriptural knowledge." Indeed, to them this earliest form of Sufism was a sound branch of knowledge because it was anchored in the framework of traditionalist theology. ${ }^{6}$ It were later Sufis, such as Abū Ḥāmid al-Ghazālī

4 I refer here, of course, to George Makdisi's well-known article in which he aimed to prove that Ibn Taymiyya was a Sufi of the Qādiriyya order. See: George Makdisi, "Ibn Taymīya: A Șūfĩ of the Qādiriyya Order," American Journal of Arabic Studies, vol. 1 (1974): 118-29. For other articles about Ibn Taymiyya's relationship with Sufism, see: Thomas Michael, "Ibn Taymiyya's Sharh on the Futūḥ al-Ghayb of 'Abd al-Qādir al-Jīlānī," Hamdard Islamicus 4:2 (1981): 3-12, and Th. Emil Homerin, "Ibn Taymiyya's Al-Ṣüfı̀ah wa-al-Fuqarä’," Arabica 32 (1985): $219-44$.

5 Ovamir Anjum, "Sufism Without Mysticism? Ibn Qayyim al-Ğawziyyah's Objectives in Madāriğ al-Sālikin," in A Scholar in the Shadow, 185.

6 I use the term "traditionalism" to refer to the school of thought identified as the ahl al-hadith, "the partisans of tradition," who base their religious knowledge on the Qur'an, the Sunna, and the consensus $(i j m \bar{a})$ of the scholars rather than reason. They were mainly represented by the Hanbalites, but also by some of the Shāficites and Mālikites, although the latter two groups would increasingly side with the Ash'arite school in the course of the Islamic Middle Period. Nevertheless, some of Ibn Taymiyya's students were still Shāfíites, such as Ibn Kathīr and al-Dhahabī, and clearly took a traditionalist stance in their theology. Traditionalist theology opposed and often clashed with the rationalist approach of the ahl al-kaläm or mutakallimūn, the partisans of speculative theology, who would have been most strongly represented by the Ash'arites in the Mamluk period. Note that kalām-scholars also made use of tradition, but differed from traditionalists in the degree that reason could be applied to extract knowledge from the sources. For this distinction see: George Makdisi, "Ash'arī and the 
(d. 505/1111), Muhyī al-Dīn Ibn al-'Arabī (d. 638/1240), and Muḥammad b. 'Abd al-Haqq Ibn Sabin (669/1270), who intermingled the spiritual path with philosophy and speculative theology ('ilm al-kaläm), which resulted in heresies in their writings. Ibn Taymiyya argues that:

This is in contrast with the pious men ('ubbād) from 'the folk of the Sunna and Hadith' and their Sufis (ahl al-sunna wa-l-hadith wa-șüfiyyatihim), such as as-Fuḍayl b. 'Iyāẹ, Ibrāhīm b. Adham, Abū Sulaymān al-Dārānī, Ma'rūf al-Kharkhī, al-Sarrī al-Saqațī, al-Junayd b. Muḥammad al-Qawārīrī, Sahl b. 'Abd Allāh al-Tustarī, and 'Amr b. 'Uthmān al-Makkī. Now, these were among the most splendid people to disavow those who were more virtuous than the philosophers, such as the Mu'tazila and the Kullābiyya from the speculative theologians (ahl al-kaläm); so just imagine how much more [they would have rejected] the philosophers! ${ }^{7}$

The above quote is representative of Ibn Taymiyya's vision of early "authentic Sufism," which he links to this very list of names of Sufi authorities in several of his writings. Only a few later shaykhs, among whom he counted the Hanbalite Sufi 'Abd al-Qādir al-Jīlānī (or al-Jīili) (d. 561/1166), were able to live up to the example of these early figures. To Ibn Taymiyya, they embodied the spiritual path because they adhered to the sound, correct creed ('aqīda, or itiquad); that is, they adhered to the traditionalist creed of the ahl al-hadith, or ahl al-sunna wa-l-hadith as he calls it here, as advocated mostly by the Hanbalites.

Although it may not be possible to speak of a neatly defined, distinct spiritual method that made up the type of Sufism referred to and envisioned by Ibn Taymiyya, we can at least observe that there indeed existed a tradition of Sufism that was particular to traditionalist Sunnite circles. This form of Sufism, which I like to call "traditionalist Sufism" because of its concurrence with traditionalist theology, indeed existed well before Ibn Taymiyya, and frequently clashed with the growing trend that increasingly partnered Sufism with rationalist theology, as articulated by the Ash'arite school in particular. ${ }^{8}$

Ash`arites in Islamic Religious History," Studia Islamica, no. 17 (1962): 49, and for the subtleties of the differences between these trends I recommend the study of Binyamin Abrahamov, Islamic Theology: Traditionalism and Rationalism (Edinburgh: Edinburgh University Press, 1998), for the definition of traditionalism, see: ix.

7 Ibn Taymiyya, al-Radd 'alā al-Shādhilīfí ḥizbayhi wa-mā șannafa-hu fì ādāb al-țarīq, ed. 'Alī b. Muḥammad al-'Imrān (Mecca: Dār al-Ālam al-Fawā’id li-l-Nashr wa-l-Tawzī', 2009), 39.

8 This partnership between Sufism and Ash'arism had become all the more evident in Ibn Taymiyya's time. Regarding Sufism in the Mamluk period, Éric Geoffroy states that: "It is 
In his study on the formative period of Sufism, Ahmet Karamustafa points to this as well where he distinguishes between a movement of traditionalist Sufis and one of kalāmì, rationalist Sufis. Among the traditionalists he counts Abū Ṭālib al-Makkī (d. 386/996), Abū Nu'aym al-Iṣfahānī (d. 430/1038), Abū Manșūr Ma'mar (d. 418/1027), and 'Abd Allāh al-Anșāīi (d. 481/1089). ${ }^{9}$ It is noteworthy that, although Ibn Taymiyya certainly criticized several teachings of some of these four Sufi shaykhs, he would undoubtedly have agreed with Karamustafa and recognized them as traditionalists. In his Kitāb al-İmān, Ibn Taymiyya displays his reverence for the first of these, al-Makkī, by mentioning him as one of the masters of Hadith, the Sunna, and the spiritual realities (haqãa iq). ${ }^{10}$ As for the other three, in his Dar'ta'ärud al-'aql wa-l-naql we can find him either citing or referring to Abū Nu'aym, Ma'mar, and al-Anșārī as important authorities who advocated the traditionalist creed. Rather than resorting to the approach predominant in kaläm-theology, which is to apply a metaphorical interpretation $\left(t a^{\prime} w \bar{l} l\right)$ when dealing with ambiguous descriptions of God in the revelatory sources, he claims that these shaykhs affirmed all of God's divine attributes (i.e. ithbāt al-sifāt). As he contends, the traditionalists understood that in such cases $t a^{\prime}$ will is to deny the way God describes Himself in the Qur'an and the Hadith, which would ultimately lead to denying Him altogether. ${ }^{11}$

These references show firstly that there was some degree of truth to the connection Ibn Taymiyya claimed existed between traditionalism and some of the early Sufi authorities, and secondly, that he considered his own outlook on Sufism to be rooted in this tradition that far predated him. In that sense, he did not view himself as an architect of some new form of Sufism; he was simply aiming to propagate what he considered to be the way of these early masters as an alternative to the many problematic interpretations that were gaining ground during his lifetime. Although we are only scratching the surface here, it should nonetheless be clear that Sufism, within the boundaries of traditionalist theology, had a place in Ibn Taymiyya's worldview.

known that not all Sufis are Ash`arites, but it cannot be denied that Tașawwuf had already acquired respectability within the school of al-Ash'arī during the Mamluk period. This marriage, which is apparent with many medieval authors, was built on the remains of esoteric Shi'ism and Hellenistic philosophy" (my translation). Cf. idem, Le Soufisme en Égypte et en Syrie Sous les derniers mamelouks et les premiers ottomans (Damascus: Institut français d'études arabes de Damas, 1995), 95.

9 Ahmet Karamustafa, Sufism: The Formative Period (Berkeley and Los Angeles: University of California Press, 2007), 87-97.

10 Ibn Taymiyya, Kitāb al-İmān (Beirut: Dār al-Kutub al-'Tlmiyya, 1983), 205.

11 Ibn Taymiyya, Dar' ta'āruḍ al-'aql wa-l-naql, ed. Muhammad Rashād Sālim, 11 vols. (Riyadh: Jāmi'at al-Imām Muḥammad b. Sacūu al-Islāmiyya, 1991), 6:252, 256-7, 7:109. 
The next logical step would be to question whether there is any indication that Sufism was also being taught and practiced within his circle. To answer this question, however, we must look beyond Ibn Taymiyya. Despite his many writings that touch upon Sufism in some way, it is not exactly clear in how far he may have taken it upon himself to actively teach a particular method of spirituality to his followers. Most of his works on Sufism are of a polemical nature, aimed at filtering out problematic concepts or refuting heresies he found in the words of certain Sufi scholars. We do know with certainty that one of his loyal students, the Ḥanbalite Sufi 'Imād al-Dīn Aḥmad al-Wāsițī, fulfilled the role of Sufi shaykh in the Taymiyyan circle until he passed away in 711/1311. Although Ibn Taymiyya's senior, al-Wāsiți adopted the shaykh al-islām as his teacher after he had become deeply convinced that he was the greatest scholar of his age. Ibn Taymiyya in his turn appears to have been deeply impressed by al-Wāsițî's profound understanding of Sufism, and reportedly said, in praise of him: "He is the Junayd of his time."12 Note that the Baghdadi Sufi al-Junayd (d. 297/910), already mentioned in a previous citation, was one of those early Sufis Ibn Taymiyya so greatly admired. The weight of Ibn Taymiyya's words of praise for al-Wāsiți should be evident from the fact that he considered alJunayd as "someone who spoke with the words of the imams who know God by experience (al-a'immat al-'ärifin)." ${ }^{\prime 3}$

I am currently in the process of writing a detailed study of al-Wāsițīs life and teachings, so I will not delve deeply into this still little-known Sufi master here. In consideration of the subject at hand, it suffices to know that several sources affirm that al-Wāsițī taught a specific method in Sufism—or sulük as he often refers to it - to a group of Damascene traditionalists, consisting of Hanbalites and Shāfi ites, the majority of whom were followers and students of Ibn Taymiyya as well. This is clear among other things from al-Wāsițì's entry in the Tabaqāt of the Hanbalite biographer Ibn Rajab (d. 795/1392), who states that "a group of our shaykhs, and others, have learned [the spiritual way] from him."14 Ibn Rajab also tells us that al-Wāsiți authored many works on the Sufi way, and that "these are some of the most useful books on Sufism for spiritual aspirants (murïdin), and a group of the Sufis from the ahl al-hadith have

\footnotetext{
12 Zayn al-Dīn 'Abd al-Raḥmān Ibn Rajab al-Ḥanbalī, al-Dhayl 'alā țabaqāt al-ḥanābila, ed. 'Abd al-Raḥmān b. Sulaymān al-'Uthaymīn, 5 vols. (Riyadh: Maktabat al-'Ubaykān, 2005), 4:382.

13 Ibn Taymiyya, Kitāb al-ṣafadìyya, ed. Muhammad Rashād Sālim, 2 vols. (Cairo: Maktabat Ibn Taymiyya, 1986), 1:266.

Ibn Rajab, Dhayl, 4:383.
} 
derived benefit from them..."15 Furthermore, two of Ibn Taymiyya's most distinguished students, Ibn al-Qayyim and the historian and Shāficite jurist Shams al-Dīn al-Dhahabī (d. 748/1348), were both also students of al-Wāsițī. The former calls al-Wāsiți "our shaykh" where he cites him to explain several Sufi terms in his Shifä’ al-'alīl. ${ }^{16}$ Likewise, al-Dhahabī mentions al-Wāsiți several times in his biographical works, always referring to him as "our shaykh," and states in his Tärïkh that he sat in his classes and benefitted from him. ${ }^{17}$

It should not come as a surprise, then, that the Hanbalite Sufi al-Ba'labakki also studied under both Ibn Taymiyya and al-Wāsițī. In fact, as we shall see below, al-Ba'abakkì's intellectual context was very much defined by his membership of Ibn Taymiyya's circle, so that the Sufism to which he was exposed by al-Wāsițī must certainly have been rooted in traditionalist theology. In light of what I have tried to sketch here, I believe that his Risālat al-sulük should therefore be seen as a product of traditionalist Sufism.

\section{The Life and Career of al-Ba'labakkī}

He is mentioned in the biographical dictionaries as Zayn al-Dīn Abū Muhạmmad 'Abd al-Raḥmān b. Maḥmūd al-Balabakkī, or al-Ba lī.18 Born in $675 / 1276$, he was a native of the small city of Baalbek in current Lebanon. In spite of Baalbek's importance as a center of Hanbalism at that time, he spent the greater part of his life in Damascus. ${ }^{19}$ It may very well have been that he was drawn to Damascus because of the many Hanbalite authorities of repute that were based there. Besides Damascus, he also traveled to Hama

\footnotetext{
15 Ibid., 4:382.

16 Muḥammad Ibn Abī Bakr Ibn Qayim al-Jawziyya, Shifä’’ al-'alïl fì masāil al-qaḍā’ wa-lqadar wa-l-hikma wa-l-tallill (Beirut: Dār al-Márifa, 1978), 16.

17 See for instance: Shams al-Dīn Muhammad b. Ahmad al-Dhahabī, Kitāb tadhkirat al-ḥuffāz (Beirut: Dār al-Kutub al-'Ilmiyya, 1998), 4:191, and also by al-Dhahabī: Dhayl tārīkh al-islām, ed. Māzin Sālim Bā Wazīr (Riyadh: Dār al-Mughnī li-l-Nashr wa-l-Tawzī‘, $1988), 126$.

18 It is thus written in the manuscript of Risālat al-sulūk, and also in: Abū al-Fidā’ Ismāêl b. 'Umar Ibn Kathīr, al-Bidāya wa-l-nihāya, ed 'Alī Shīrī, 14 vols. (Beirut: Dāàr Ihyā̄' al-Turāth al-'Arabī, 1988), 14:194, and also: Ibn Ḥajar al-'Asqalānī, al-Durar al-kāmina fì a'yān al-mi'a al-thāmina, ed. Muhammad 'Abd al-Mu'īd Ḍān, 6 vols. (Hyderabad: Majlis Dāirat al-Ma'ārif al-'Uthmāniyya, 1972), 3:139. Ibn Rajab, however, has "Abū al-Faraj" instead of "Abū Muḥammad," and "Ubayd" instead of "Ubaydān," cf. Ibn Rajab, Dhayl, 5:50.

19 Henri Laoust, "Le hanbalisme sous les Mamelouks bahrides," Revue des Études Islamiques, no. 28 (1960): 66-8.
} 
to study with its judge, Sharaf al-Dīn b. al-Bārizī al-Ḥamāwī (d. 738/1337) who, according to Ibn Rajab, often extolled him after that, saying that he had never seen anyone like him. ${ }^{20}$

In Damascus he studied jurisprudence under Ibn Taymiyya and entered a master-disciple relationship (șuḥba) with al-Wāsițī, under whose guidance he was trained in sulūk. ${ }^{21}$ It was thus al-Wāsitịi, and not Ibn Taymiyya, who was his shaykh in Sufism. Although this does not appear to be confirmed in the biographical sources, I suspect that al-Balabakkī may have traveled with Ibn Taymiyya to Cairo in 705/1306 and stayed with him in Egypt for some time. We have at our disposal a letter by al-Wāsiți that addresses seven of Ibn Taymiyya's followers by name, among whom al-Ba labakkī, urging them to stick by their shaykh's side and support him unconditionally. Since al-Wāsițī stayed in Damascus till his death, and we know that Ibn Taymiyya got in serious trouble with the Mamluk authorities during his stay in Egypt, it is not hard to imagine that this letter may have been sent to Cairo during those times of distress, with the aim to hearten the addressees. ${ }^{22}$

Whatever the case may be, it was Damascus where al-Ba'labakki built a career as a professional Muslim scholar. Ibn Rajab states that a group of scholars benefited from his classes in Hanbalite jurisprudence ( figh), legal theory (ușūl), and tradition (hadith), the most notable of whom was the staunch Hanbalite and admirer of Ibn Taymiyya, Izz al-Dīn Abū Ya lā Ḥamza b. Mūsā Ibn shaykh al-Salāmiyya (d. 769/1368). ${ }^{23}$ Besides teaching, al-Baclabakkī authored works in the fields of jurisprudence, Hadith, and Sufism. He wrote a book on legal judgments (ahkām) called al-Muțlic, which is arranged according to the chapters of Ibn Qudāma's al-Muqnic and provides proofs by citing authentic (sahịh) and good (hasan) prophetic reports from the six canonical Hadith collections. ${ }^{24}$ Al-Balabakkī also produced at least two figh manuals,

\footnotetext{
$20 \quad$ Ibn Rajab, Dhayl, 5:51.

21 Ibid., 5:50.

22 'Imād al-Dīn Aḥmad al-Wāsițī, al-Tadhkira wa-l-i'tibār wa-l-intiṣār li-l-abrār, ed. 'Alī Ḥasan 'Alī 'Abd al-Majīd (Beirut: Dār al-Bashā’ir al-Islāmiyya, 2014), 21-3. Caterina Bori gives a short, but comprehensive overview of the contents of this letter in her article "Ibn Taymiyya wa-Jamāatuhu," 26-9.

23 Ibn Rajab, Dhayl, 5:51-2. For al-Ba'labakkī's student 'Izz al-Dīn, see: Ibn Ḥajar, al-Durar, 2:196, Șalāḥ al-Dīn Khalīl al-Ṣafadī, al-Wāfí bi-l-wafayāt, ed. Aḥmad al-Arnāūṭ \& Turkī Muștafāā, 29 vols. (Beirut: Ḍar Iḥyā̄ al-Turāth, 2000), 13:111, 'Abd al-Ḥayy Ibn al-'Imād al-Ḥanbalī, Shadharāt al-dhahab fì akhbār man dhahab, ed. Maḥmūd al-Arnāūut, 11 vols. (Damascus and Beirut: Dār Ibn Kathīr, 1986), 8:367.

24 'Abd al-Q̣āir b. Aḥmad Badrān, al-Madkhal ilā madhhab al-imām Aḥmad b. Hanbal, ed. 'Abd Allāh b. 'Abd al-Muḥsin al-Turkī (Beirut: Mu’assasat al-Risāla, 1985), 468.
} 
the first being a commentary on the above mentioned Muqnic, the second being Zawā'id al-muharrar 'alā l-muqni'. ${ }^{25}$ In Sufism there are no other titles that I have been able to find by his hand other than Risālat al-sulük.

There is very little to say about al-Balabakkī's role as a Sufi shaykh. It is only through Risālat al-sulük that we can get a very basic image of his perception of the spiritual way. Thanks to Ibn Rajab's entry on him, we can at least say that Sufism appears to have been an important part of his scholarly life. The Hanbali biographer relates that al-Balabakkī experienced spiritual states $(a h \mathfrak{h} w \bar{a} l)$ and saintly miracles (karāmāt). It was said, for instance, that every year he would be aware which night was the Night of God's Decree (i.e. laylat al-qadr).

In 718/1318 one of his miraculous claims gave rise to such controversy that he was eventually brought to trial before judges and jurists in the Dār al-Sa'āda of Damascus. Al-Ba'labakkìs case came to light after some of his companions had found out about a certain spiritual state he claimed to have reached, for which they were apparently able to provide written proof in his handwriting. The following claims were reportedly made by him:

He [claimed that he] saw the Real (glorified and exalted is He) and contemplated the World of Sovereignty (malakūt). He saw Paradise ( firdaws) and ascended above the Throne [of God]. He heard divine speech (khitāab), and it was said to him: 'I have granted you the spiritual state of shaykh 'Abd al-Qādir [al-Jīlānī]. [He claimed] that God (exalted is He) took something like a cloak from 'Abd al-Qādir and put it on him, and that He gave him three drinks of different colors. He sat before God, together with Muhammad, Abraham, Moses, Jesus, and al-Khaḍir (peace be upon them), and it was said to him: 'this is a rank (makān) that no saint (walī) can surpass.' It was also said to him: 'You will be the spiritual axis $(q u t ̣ b)$ for twenty years.'26

Albeit without much detail, Ibn Kathīr affirms that al-Ba labakkī made claims regarding some spiritual experience: "Something either afflicted his mental state ('aql) or he lost his mind. Or [perhaps] he had been so devoted to disciplining [his ego] that his inward being was burning with hunger. He saw

\footnotetext{
25 Ismāīil b. Muḥammad al-Baghdādī al-Bābānī, Hadìyyat al-'ārifin: asmāà al-mu’allifin wa-āthār al-mușannifinn, 2 vols. (Istanbul: Wikālat al-Ma'ārif, 1951), 1:526, Ibn Rajab, Dhayl, 5:52. The Zawā’id has been published under the name of 'Abd al-Rahmmān b. 'Ubaydān al-Ḥanbalī al-Dimashqī, Zawā̉id al-kāfì wa-l-muharrar 'alā l-muqni', 2 vols. (Riyadh: al-Mu’assasa al-Sa'īiliyya, 1981).

26 Ibn Rajab, Dhayl, 5:51.
} 
figments of the imagination (khayālät) that have no reality, believing that they were something supernatural $(a m r k h \bar{a} r i j \bar{\imath})$, while they were only a false figment of the imagination." ${ }^{27}$ While Ibn Kathīr does not state what it was that al-Balabakkī claimed to have experienced, it appears from Ibn Rajab that it concerned an heavenly ascension, reminiscent of the Prophet Muhammad's mir $r \bar{a} j$. His account suggests that al-Ba labakki thereby attained the rank of the $q u t \underline{b}$, which in Sufi terminology is generally considered to be the highest degree of sainthood. Al-Jilānì's presence in the account is also noteworthy, since this Sufi was well-respected by Ibn Taymiyya and the Hanbalite community, and thus an archetype of the form of Sufism accepted among traditionalists. That al-Ba'labakkîs supposed claims were so controversial that the death-penalty was actually considered is hinted at when Ibn Rajab states that the judge decided to spare his life. The seriousness with which his case was dealt with is not so strange in view of its historical context. In the Mamluk period, claims to heavenly ascension were indeed very rare and were known to have met with great controversy. Sufis were obviously very careful in claiming such a thing for themselves. ${ }^{28}$ While al-Balabakki was not sentenced to death, the final outcome must nevertheless have struck a severe blow to his career. He was censured for his claims and had to renew his profession of Islam. The judge's sentence was that he be chastised and detained for some days. He was also forbidden to give fatwas or produce marriage contracts. Ibn Rajab's account concludes that, after that, al-Ba'labakkì's mistake became clear to him. Rather than having physically ascended through the heavens, he affirmed that what he had experienced were spiritual contemplations (shawāhid) and lights of the hearts (anwār qalbiyya). ${ }^{29}$

Al-Balabakkī was eventually able to pick up his scholarly life once more, teaching Islamic sciences at several madrasas in Damascus. He passed away in 734/1333 in his hometown of Baalbek, and was reportedly escorted to the cemetery at the city's Sațhān gate by a crowd of locals, who carried him above their heads in honor. There was also an absentee funeral prayer (șalāt al-ghä̉ib) for him in Damascus, which suggests that in the end he must have enjoyed something of a respectable position in the Mamluk capital of Shām..$^{30}$

27 Ibn Kathīr, al-Bidāya, 14:194.

28 The matter of mirāj among Mamluk Sufis has been treated by Éric Geoffroy in Le Soufisme, 434 (I owe this reference to Christian Lange).

29 Ibn Rajab, Dhayl, 5:51.

3o Ibn Rajab, Dhayl, 5:52, Ibn Kathīr, al-Bidāya, 14:194. 


\section{Some Notes on Risālat al-sulūk}

My road towards al-Ba'labakkìs Risālat al-sulük started with the question whether any of al-Wāsițī's students or affiliates produced writings in the field of Sufism. As I examined the sources on al-Balabakkī, I found both Ibn Rajab and Ibn Kathīr confirming that this was the case with regard to him, with the latter explicitly stating that he wrote on Sufism and the works of the hearts (al-tașawwuf wa-a'māl al-qulüb). ${ }^{31}$ Without any mention of a title, I tried my luck by searching for al-Ba'labakkī's name in Khizānat al-turāth, a database of Arabic manuscripts that can be accessed through al-Maktaba al-shämila, a digital library of Islamic literature. I thus found that there is a tract on Sufism by the title of Risālat al-sulük that is kept in the Zāhiriyya Library of Damascus, which I was subsequently able to confirm in the catalogue of the Zāhiriyya collection of Sufi literature. ${ }^{32}$ I could not find any other copy of the Risāla in the online databases or catalogues I consulted, so that the Damascene version appeared to be the only way to gain access to it. Unfortunately, due to the current deplorable situation in Syria, I was unable to travel to Damascus to view it myself. It is thanks to the generous help of Dr. Khayr Allāh al-Sharif that I received the invaluable photographs of the Damascene manuscript on which I was able to base my edition. Because of this, there are limits to the degree that I can give an in-depth description of the manuscript here. Nonetheless, owing to the information found in the catalogue of the Zāhiriyya Library and the Khizänat al-turāth, there is still a thing or two to be said in its regard.

\section{Concerning the Manuscript}

The manuscript of Risālat al-sulük is part of a collective volume that is held in the Zāhiriyya Library under shelf-number 6595. According to the Khizānat al-turāth, the manuscript contains at least four other treatises, namely:

- Al-Risāla al-qudsiyya bi-adillatihā al-burhāniyya, a work on creed by Abū Ḥāmid al-Ghazālī (d. 505/1111). ${ }^{33}$

- Ajwibat al-Shādhilī, which will be mentioned below. ${ }^{34}$

31 Ibid.

32 Khizanat al-turath, 89:165, and Muhammad Riyāḍ al-Māliḥ, Fihris makhṭūṭāt dār al-kutub al-z̧ăhiriyya: qism al-tașawwuf, 3 vols. (Damascus: Maktabat al-Hijāz, 1978), 1:636-7.

33 Khizānat, 75:514.

34 Ibid., 88:666. 


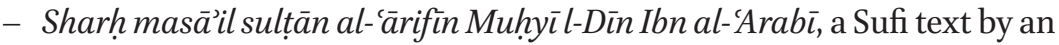
unknown author. ${ }^{35}$

- Al-Muntakhab al-rafì al-asnā fì l-tașarrufāt bi-asmǟ Allāh al-ḥusnā, a Sufi text by Aḥmad b. 'Alī b. Yūsuf al-Būnī (d. 622/1225). ${ }^{36}$

The text of Risälat al-sulūk starts on the sixth line of folio $18 \mathrm{~b}$ (verso), the first four lines of which are the final lines of another treatise that I have not been able to identify. ${ }^{37}$ The fifth line is kept empty so as to separate the two treatises from each other.

There is no reason to doubt al-Balabakkīs authorship of the Risāla. After the basmala and an invocation for the Prophet, the treatise starts by setting forth its author's full name as follows: "Says the shaykh, the imam, the scholar, the traditionist, the learned, the pious, the knower [of God], Zayn al-Dīn Abu Muḥammad 'Abd al-Raḥmān b. Maḥmūd b. 'Ubaydān al-Ba labakkī." Although the manuscript does not contain a title, "Risālat al-sulük," as it is called in the Zāhiriyya catalogue, appears fitting. The use of the word "sulūk" as the collective term for the spiritual way to God on folio $18 \mathrm{~b}$ shows that this is exactly the subject with which the epistle is concerned.

The manuscript's writing is in clear naskhī script, with 21 lines per page and about 12 words per sentence, on $29,5 \times 20,05 \mathrm{~cm}$ pages, with $3 \mathrm{~cm}$ margins. ${ }^{38}$ Risālat al-sulük ends on folio 21a (recto), on the end of the page's seventeenth line, which is directly followed by four more lines in the same handwriting that are not part of our treatise. Unlike folio $18 \mathrm{~b}$, this is not indicated by an empty line. These four final lines on folio 21 a are possibly the copyist's own words, meant to introduce a new treatise that follows on the folio's verso. It reads:

Answers by our shaykh, our blessing: the shaykh, the imam, the scholar who puts his knowledge in practice (al-âlim al-âmil), the godly, the renunciant, the unique, the learned, the most erudite, our master and our spiritual guide (qudwa) to God (exalted is He): Sharaf al-Dīn Abī Sulaymān Dāwūd, the son of the servant in need of God (exalted is He), the late Abī Hafș 'Umar b. Ibrāhīm al-Shādhilī—may God be pleased with him and make him be pleased! May He make Paradise his final destiny and dwelling, and may He unite us in the abode of honor, in a state of

35 Ibid., 89:584.

36 Ibid., 9o:87.

37 The first four lines on folio 18b contain an account about 'Abd Allāh b. al-Zubayr. I have been able to identify this through Ibn Taymiyya's Majmū' fatāwā, 22:605.

38 Al-Mālị̣, Fihris makhțūtāat, 637. 
blessing and wellbeing, without hardship, in the company of Muhammad and his family—amen, amen, amen! ${ }^{39}$

According to the catalogue of the Zāhiriyya Library, the treatise that follows on the verso of folio 21 is known as Ajwibat al-Shādhilī, by the Shädhilite shaykh Dāwūd Ibn Bākhilā—or Mākhilā—al-Iskandarī (d. 733/1332). ${ }^{40}$ This is a short work, about 16 folios long, aimed to answer several questions concerning the Prophet Muhammad's nightly journey to Jerusalem and the heavens (i.e. al-isrä' $\left.w a-l-m i{ }^{\prime} r a \bar{j}\right)$. If, as I suspect, the words cited above are indeed of the copyist's own composition, this would mean that our manuscript must have been copied by a contemporary of al-Baclabakkī, and that the copyist was a disciple of Dāwūd al-Shādhilī. As we have seen, our Ḥanbalite Sufi passed away in 734/1333, which would have been about a year after the Shādhilī shaykh. It may therefore very well have been copied while al-Ba labakkī was still alive. This, however, can only be established with certainty by studying Ms 6595 in its entirety, which, as mentioned, is currently impossible.

There are several instances where we find things written in the margins of Risālat al-sulük. The folio-pagination is written in the upper-left corner of each folio's recto. Folios 2oa and 21a have the final letters of a word that the copyist was not able to fit in its entirety within the borders its respective line written in the margins. Folio $19 \mathrm{~b}$ has a suggestion for a different word written in the right margin, and the first word of the following page in its lower left corner. There is

39 The Arabic reads:

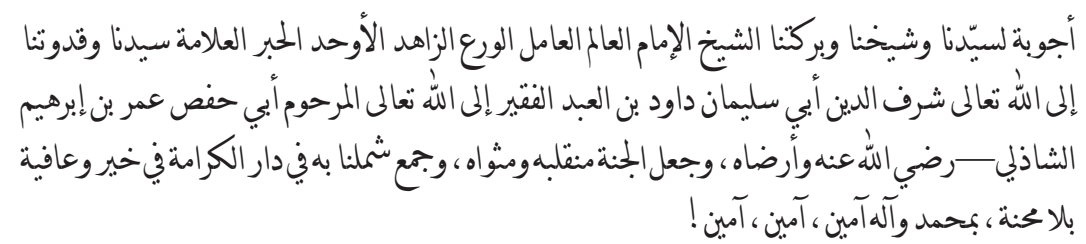

al-Māliḥ, Fihris, 1:17-8. Dāwūd al-Iskandarī was the successor of Ibn 'Ațā̄ Allāh's al-Iskandarī (d. 709/1309) as the head of the Shādhili order. A brief overview of some of his teachings can be found in Richard J.A. McGregor, "The Concept of Sainthood According to Ibn Bāḩilā; A Šādilī Shaykh of the 8th/14th Century," in Le saint et son milieu ou comment lire les sources hagiographiques, ed. Rachida Chih and Denis Gril (Cairo: Institut Français d'Archéologie Orientale, 2000), 33-49, and by the same author: Sanctity and Mysticism in Medieval Egypt: The Wafä' Sufi Order and the Legacy of Ibn 'Arabī (Albany: State University of New York Press, 2004), 32-47. For his biography, see: al-Bābānī, Hadiyyat al-'ārifin, 1:36o-1; Sirāj al-Dīn Abū Ḥafṣ 'Umar Ibn al-Mulaqqin, Ṭabaqāt al-awliyā’, ed. Nūr al-Dīn Sharībah (Cairo: Maktabat al-Khānjī, 1994), 517-18; Muḥammad b. Muhammad Makhlūf, Shajarat al-nūr al-zakiyya fi țabaqāt al-Mālikiyya, ed. 'Abd al-Maj̄̄d Khayālī, 2 vols. (Beirut: Dār al-Kutub al-'Ilmiyya, 2003), 1:293; and, al-'Asqalāni, al-Durar, 2:226. 
a small note under the final line of the above-mentioned treatise that precedes our Risäla on folio 18b, stating that it has been read by one Rajab Jiddī. In the left margin of our treatise's final page we find two such notes, the first of which is by the same Jiddī, the second of which, right under the former, is by one Taqi al-Dīn al-Huṣnī, who adds that he read it in 1079/ca. 1668.

The manuscript appears to be in excellent shape, apart from a large stain that covers about one-sixth of every folio, which was likely caused by humidity. There is only one word that has become entirely illegible due to this. The rest of the words that are affected by the stain remain readable, so that the process of editing Risālat al-sulūk did not prove difficult.

\section{Concerning the Edition and the Translation}

- Because I have given priority to making the Arabic text as readable as possible, I have inserted punctuation and Arabic diacritical marks where I found this fitting.

- In the Arabic text, citations from the Qur'an are put between special brackets (i.e. and the name of the süra and number of the verse(s) in question are given in a footnote. In the translation, each Qur'anic verse is directly followed by the number of the süra and the verse(s) in question between square brackets.

- In both the Arabic text and the translation, whenever a hadith is cited this is put between quotation marks, followed by a footnote that refers it to one of the well-known Hadith-compilations.

- The manuscript's folio-numbering has been put between virgules throughout the text of the edition and the translation, with '"' or 'a' to mark a recto and 'ب' or 'b' to mark a verso.

- Anything else that is inserted in the Arabic text of the edition that is not found in the manuscript has been put between square brackets. 


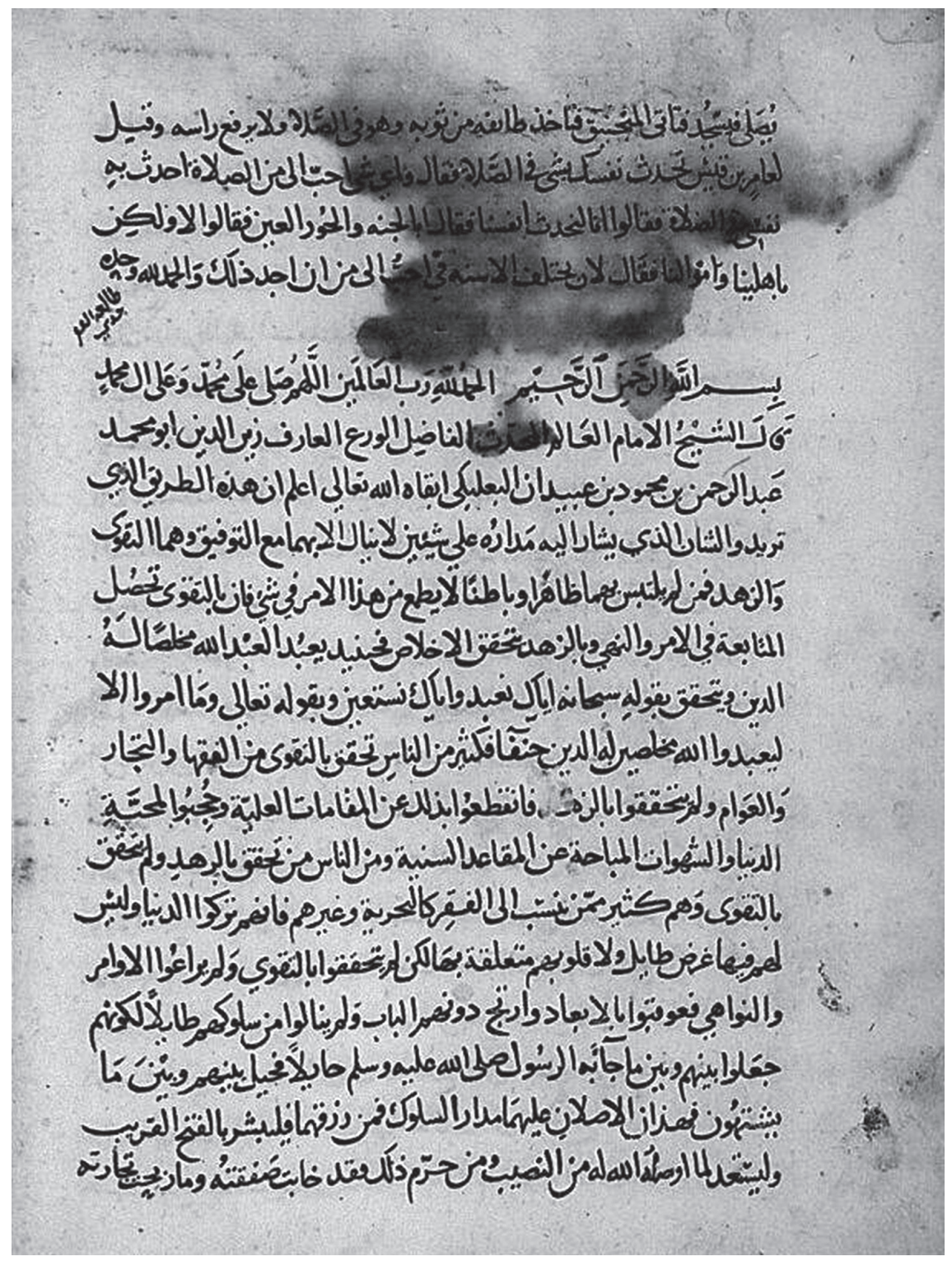

FIgURE 1 MS Zāhiriyya Library (Damascus), 6595, fol. $18 b$ (first page). 


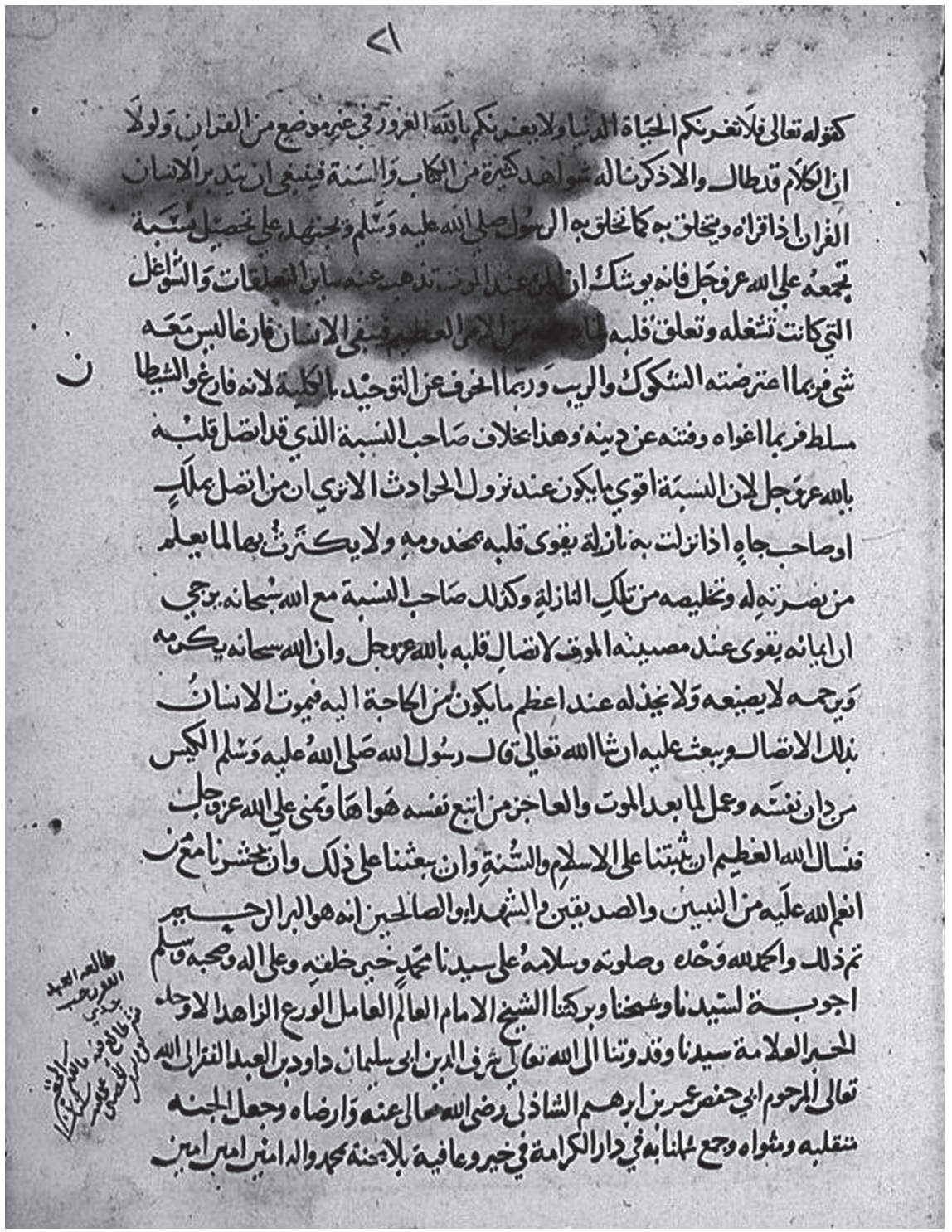

FIGURE 2 MS Zāhiriyya Library (Damascus), 6595, fol. $21 a$ (final page). 


\section{Arabic Text}

\section{رِسَالَّةُالسُّلُوكِك}

تألف

$$
\begin{aligned}
& \text { زبن الدين أبو محمد عبد الرحمن بن محمود بن عبيدان البعلبكي }
\end{aligned}
$$

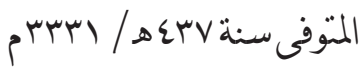

$$
\begin{aligned}
& \text { /8 18ب /بسم/اللهالرحمن الرحبم } \\
& \text { الحمد للهّرب العالمبن ، اللهم صلّي على محمد وعلى آل محمد . }
\end{aligned}
$$

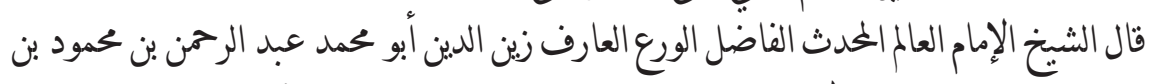

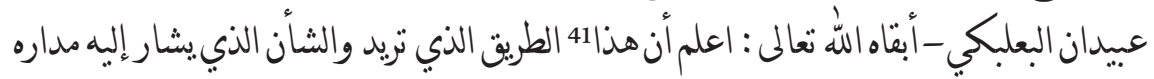

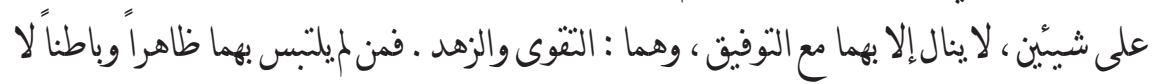

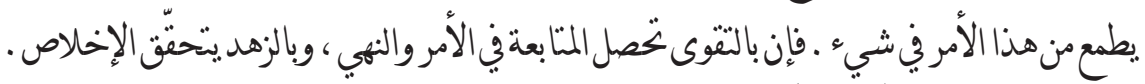

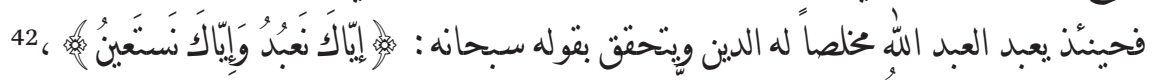
43.

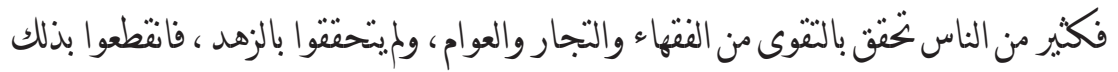

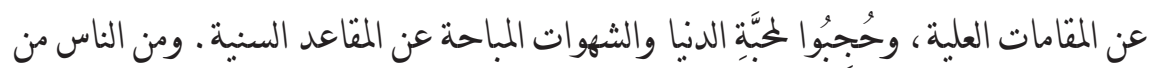
تحقق بالزهد ولمبتحقق بالققوى ، وهم كمير مُّن ينسب إلى الفقر ، كالبحرية44 وغيرهم ، فإنهم تركوا

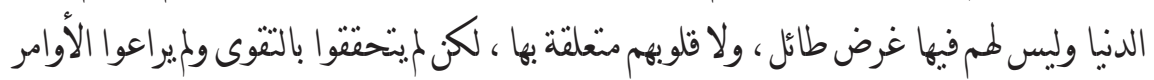
والنواهي ، فعوقبوا بالإبعاد وارنبّ دونهم الباب ، ولمينالوا من سلوكهم طائلاً لكونهم جعَلوا بينهم وبين

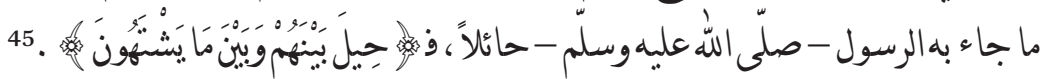

$$
\begin{aligned}
& 41 \\
& 42 \\
& 43 \text { سورة الينة: } 5 . \\
& 44 \\
& 45 \text { سورة سبا :54. }
\end{aligned}
$$


فهذان الأصلان عليهما مدار السلوكُ فمن رُزهما فليشّر بالقتح القربب ، وليستعد لما أوصله

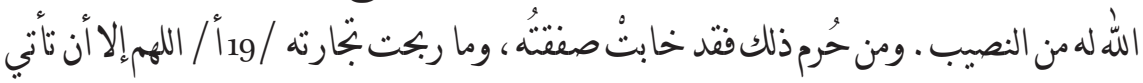

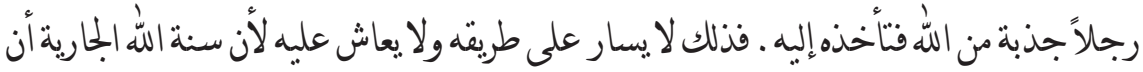

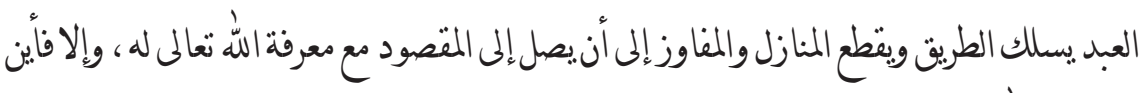

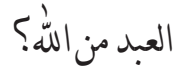

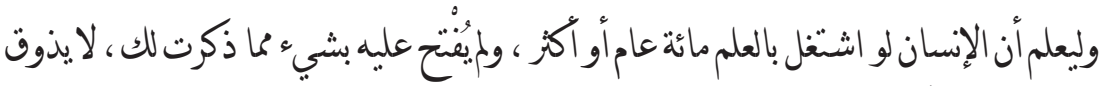

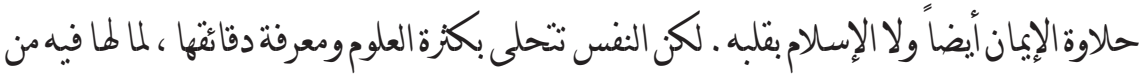

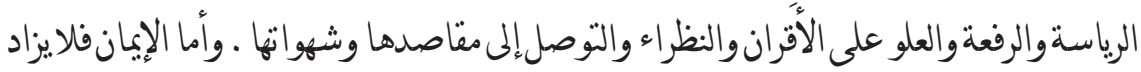
بذلك ، بل ربما قتص لككرة العمل لغير الله .

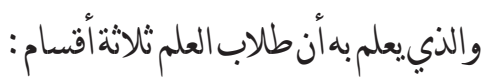
فسم طلبوا العلم لمعرفة الأحكام فقط لبس لمم غرض فيما سوى ذلك من العمل والتخلق به به بهل

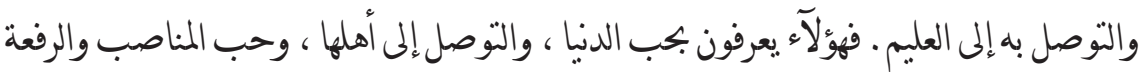

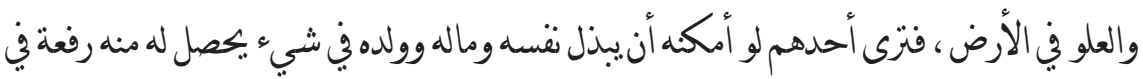

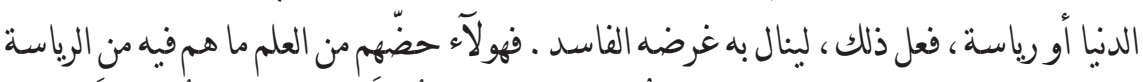

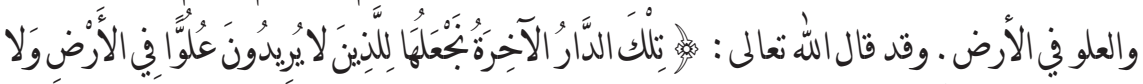

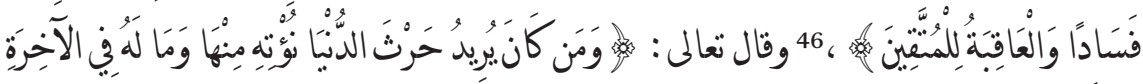

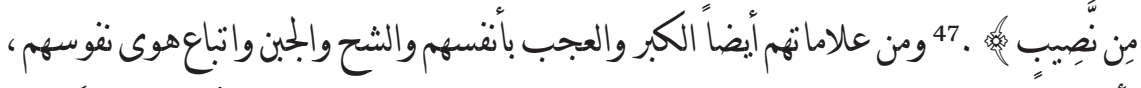

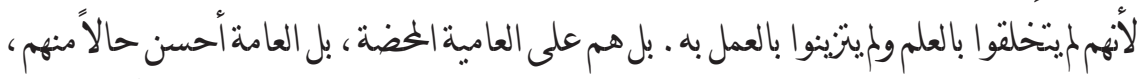

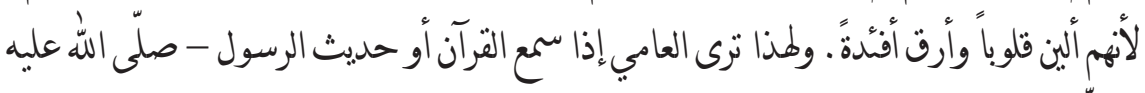

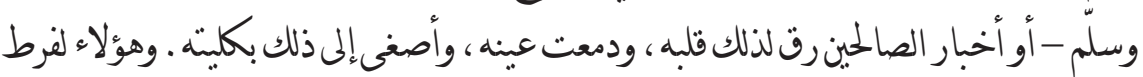

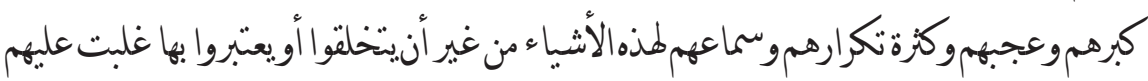


القسوة . فصاروا كمغسل الموتى في عدم الاعتبار بالموت . فنسأل الله العظيم أن لا بيجلنا من هذا

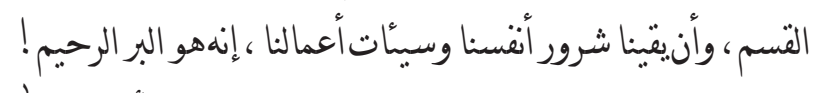

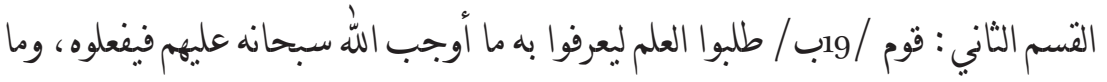

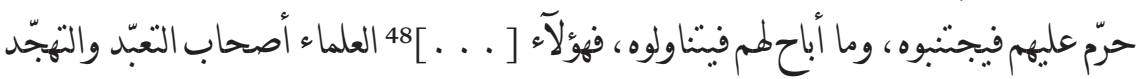

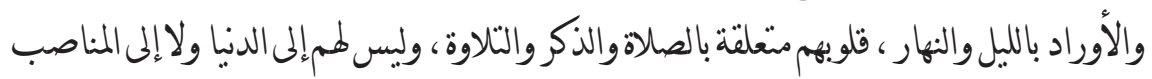

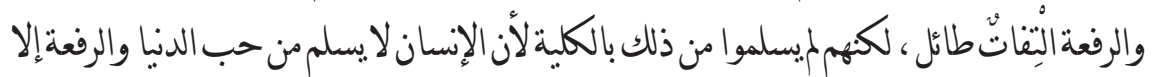

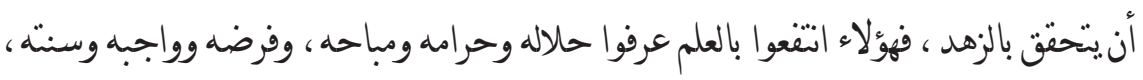

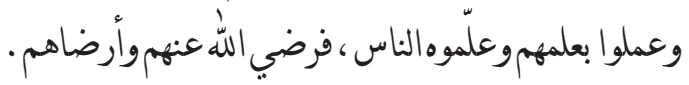
القسم الثالث: قوم طلبوا العلم لبعرفوا به العلبم سبحانه، فكان هو مقصهودهم الأول ، والعلم

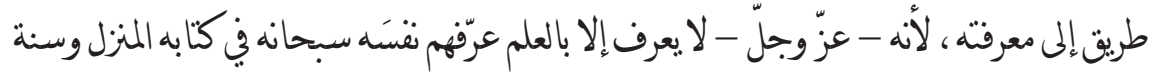

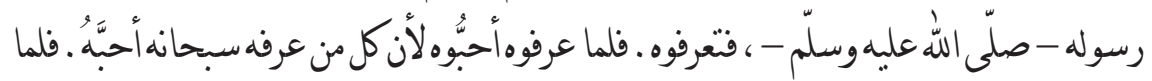
أحبوه نصحوه ، إن الخب لمن يحب نصوح، وفاموا له بالعبودية في الظاهر والباطن بما اقتضشهُ أسماؤه

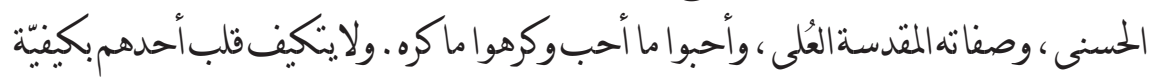

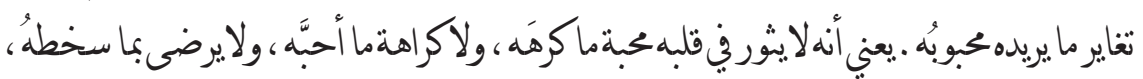

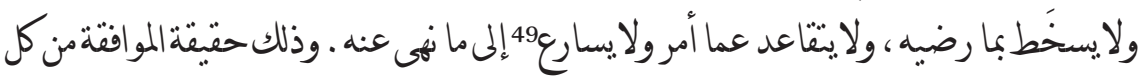

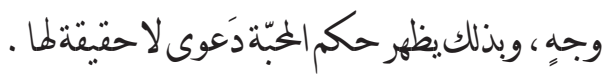

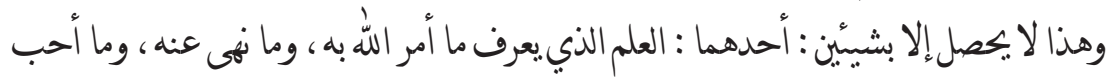

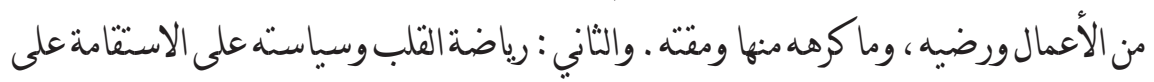

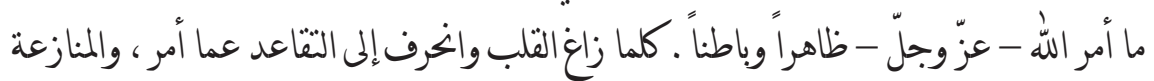

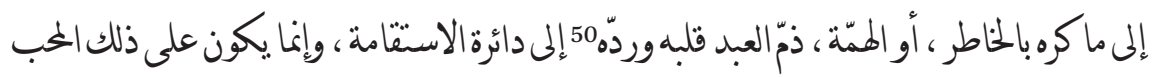

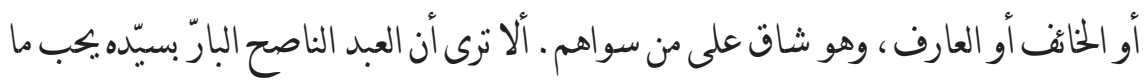

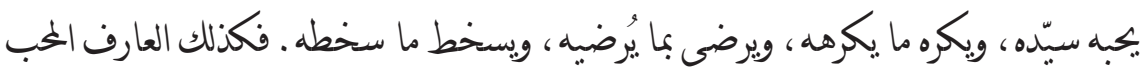

48 49 في 48 50 
/20 أ يتكيف فلبه بصفات مولاه - عزّ وجلّ - من الكرم، والحلم، والرحة ، والصبر ، والثنع ،

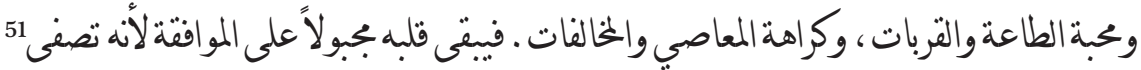

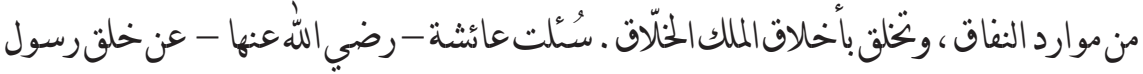

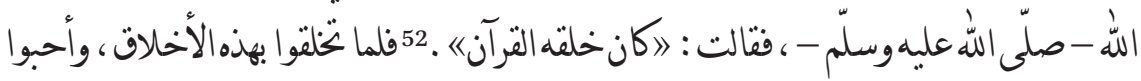

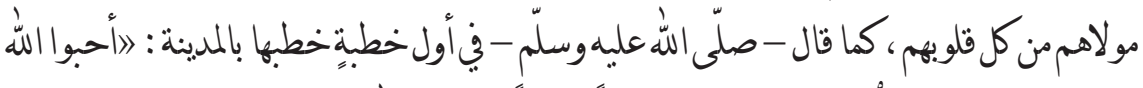

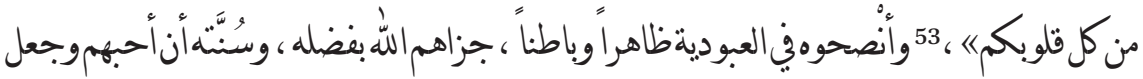

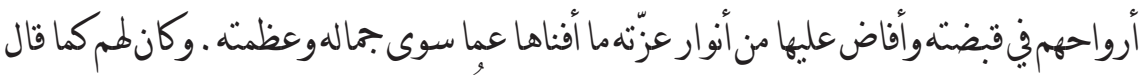

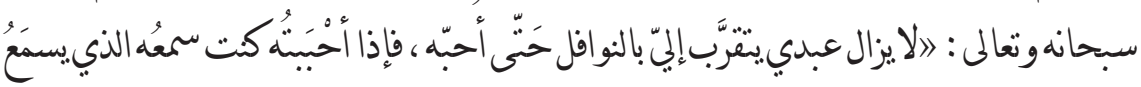

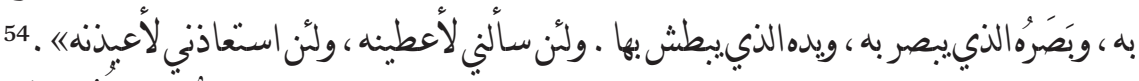

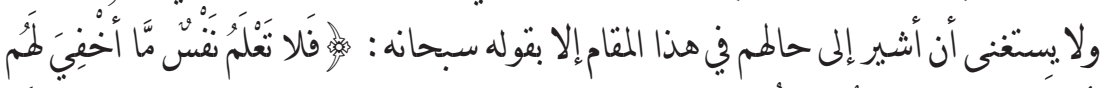

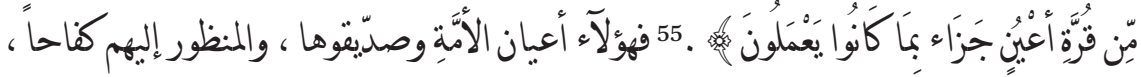

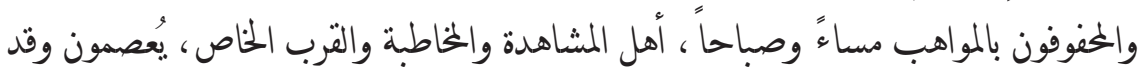
استشرفوا للجفاء ، ويؤدبون إذا بدت منهم ناكرة ، وعبن الله ترعاهم وتكأهم ، لا تزال الألوار متدليةً

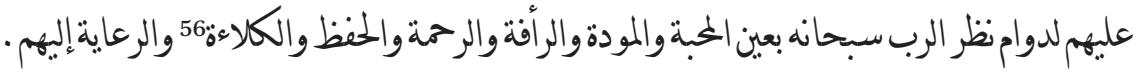
فهم الصفوة بعد الأنياء والمرسلبن وهم خلفاؤهم بين أظهر الخلق ، منهم من يقبم الدين الطاهر ، ومنهم

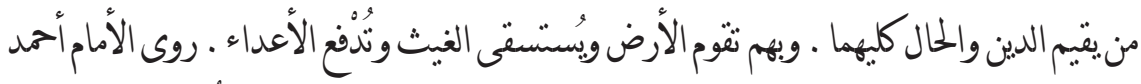

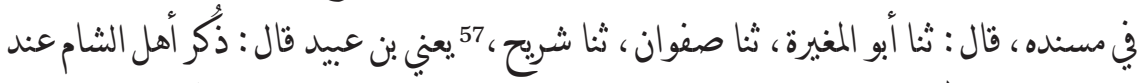

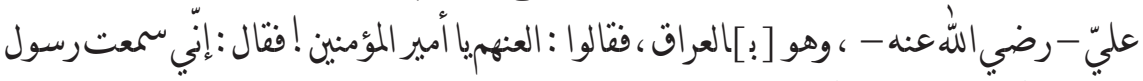

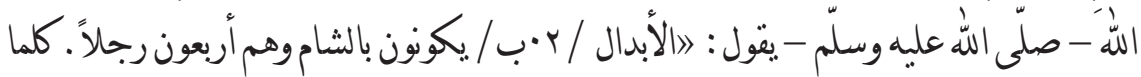

$$
\begin{aligned}
& \text { 5 } 51 \\
& 52
\end{aligned}
$$

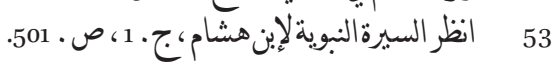

$$
\begin{aligned}
& 54 \text { رواهالبخاريفئصحيحه، ج. } 8 \text { ، ص. } 55 \\
& 55 \text { سورةالسجدة : } 17 . \\
& \text {. } 56 \\
& 57
\end{aligned}
$$


مات رجل أبدل الله مكانه رجلاً . يُستى بهم الغيث، وينّنصر بهم على الأعداء ، ويُصرف عن أهل

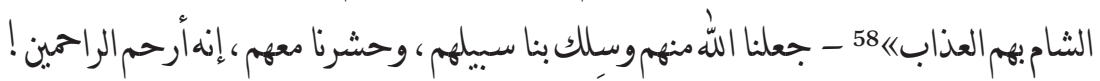

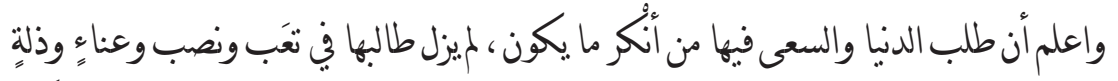

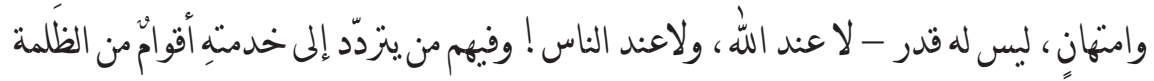
أو أعو إنهم أو غيرهِم كمن ليست له فيه عقيدة صالحة لبعينوه على دنياه وقضاء حوائجه ، فيستعبدوه بذلك ويذلوه ، وعلى تقدير أن يقبلوا علهه ويكرموه ، يكون ذلك أكبر فنة له ، وأبعد عن الله تعالى ، فإنهميصيرون صنم فلبه . كما حدث له حادثة، أو نزل بهنازلة ، توجه قلمه في قضاء حاجته ، ودفع

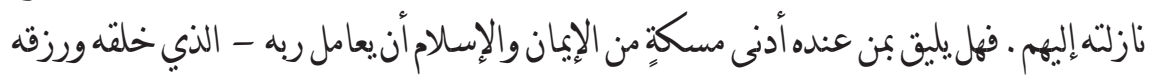

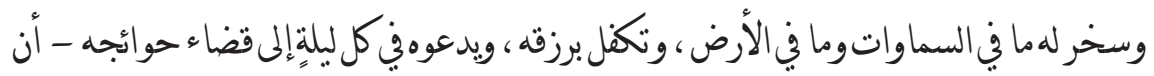

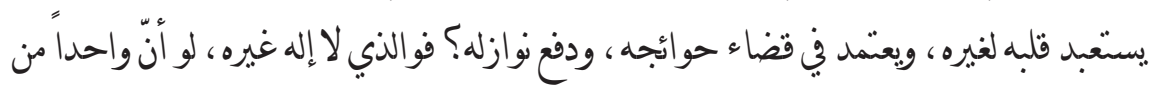

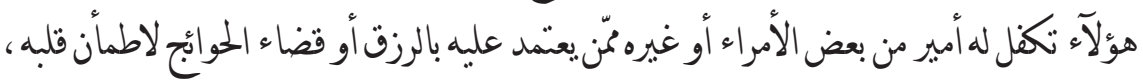

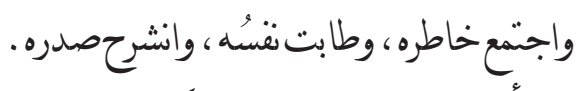

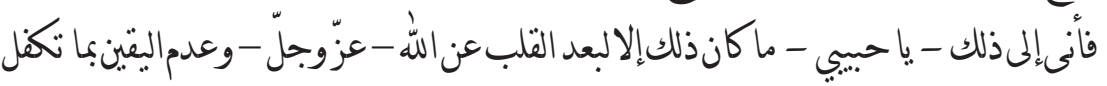

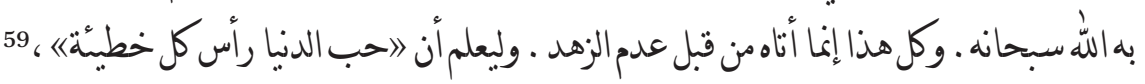

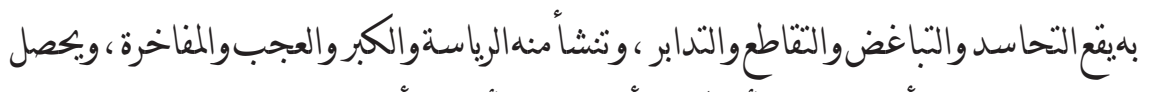

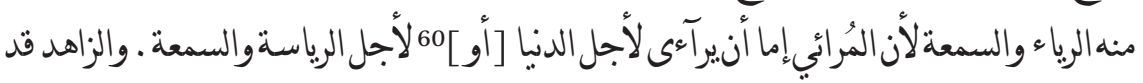

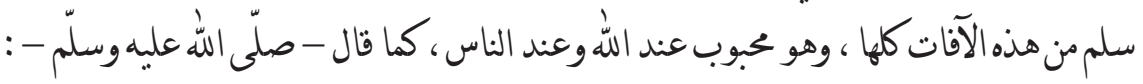

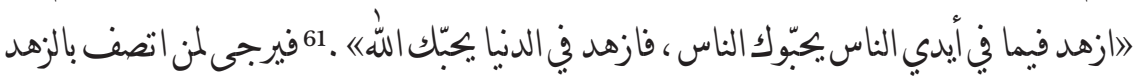
أن الله سبحانهوتعالى يأخذه إلبه بمحبته إياه .

$$
\begin{aligned}
& \text { 58 } 58
\end{aligned}
$$

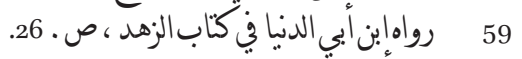

$$
\begin{aligned}
& \text { 6o }
\end{aligned}
$$

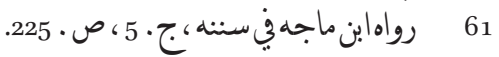




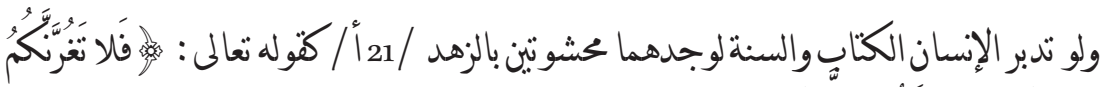

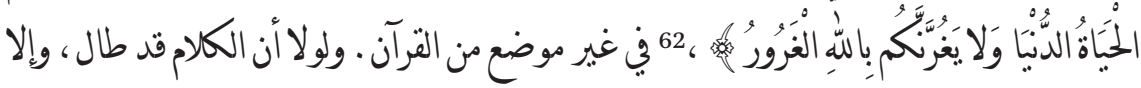

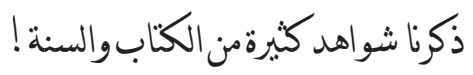

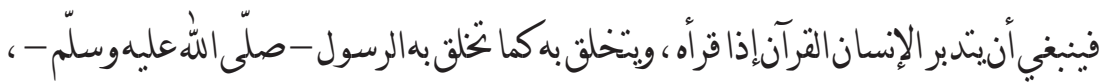

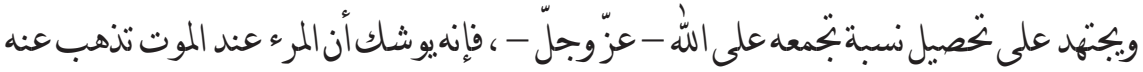

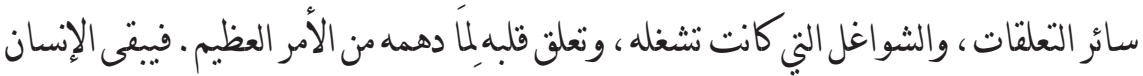

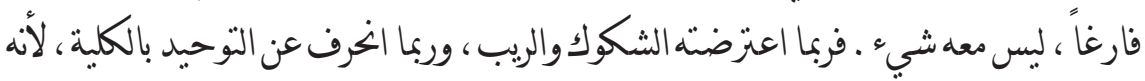

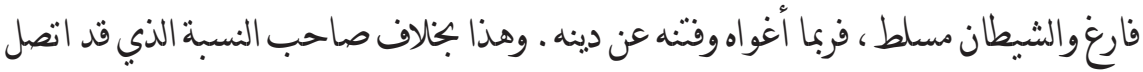

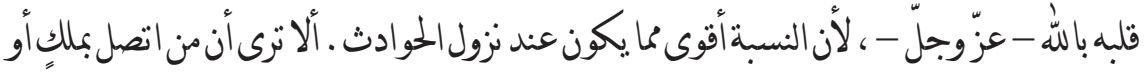

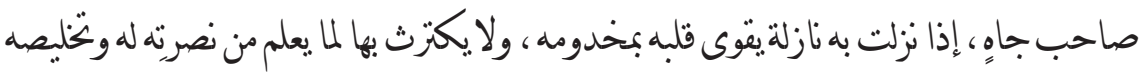

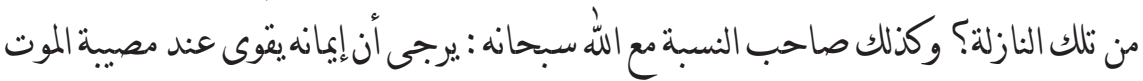

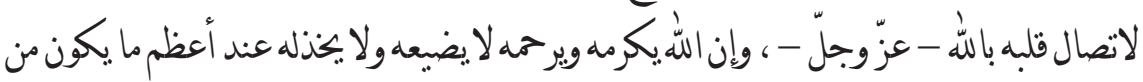

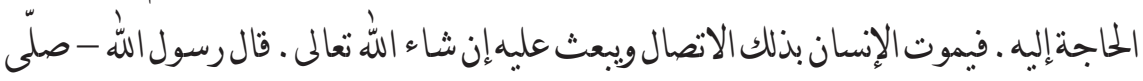

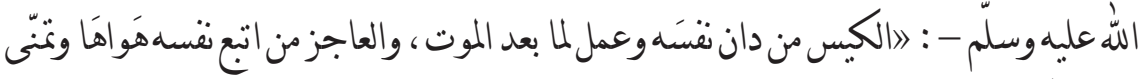

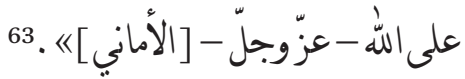

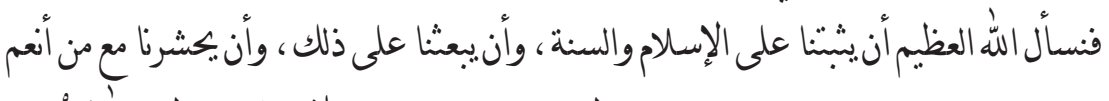

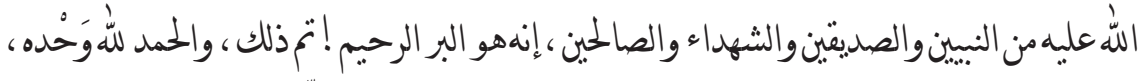

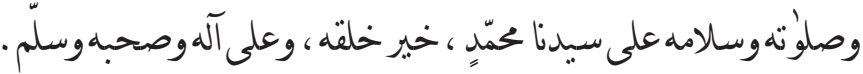




\section{Translation}

\section{Epistle on the Spiritual Way \\ (Risālat al-Sulūk)}

by

Zayn al-Dīn Abū Muḥammad 'Abd al-Raḥmān b. Maḥmūd b. 'Ubaydān

al-Ba'labakkī

/18b/ In the Name of God, the Merciful, the Compassionate

Praise be to God, the Lord of all worlds, O God bless Muhammad and the family of Muhammad!

Says the shaykh, the imam, the scholar, the traditionist (muhaddith), the learned, the pious, the knower [of God] ('ärif), Zayn al-Dīn Abū Muhammad 'Abd al-Raḥmān b. Mạ̣mūd b. 'Ubaydān al-Ba'labakkī—may God (exalted is $\mathrm{He}$ ) grant him a long life: Know that this path that you seek, and the affair (sha'n) that it alluded to [by those who follow it] revolves around two things and it is only through them that it is granted successfully. They are piety $(\operatorname{taqwa})$ and renunciation $(z u h d)$. Whoever does not clothe himself with them outwardly and inwardly does not achieve anything from this matter, for from piety results compliance with the divine command and prohibition, and through renunciation sincere devotion (ikhlāṣ) is realized. Then will the servant [truly] serve God, sincerely devoting the religion to Him, which is confirmed in God's statement (glorified is He): "You only we serve, to You alone we pray for succor" [Qur'an 1:5], and in His statement (exalted is He): "They were commanded only to serve God, sincerely devoting the religion to Him, men of pure faith" [Qur'an 98:5]. ${ }^{64}$

A lot of jurists, merchants, and common people realize piety without realizing renunciation. They are thereby cut off from elevated stations, and because of [their] love for this world and licit desires, they are veiled from sublime seats $\left(\right.$ maqū $\left.{ }^{c} i d\right){ }^{65}$

64 I rely on A.J. Arberry's translation of the Qur'an throughout the English translation of Risālat al-sulūk, albeit with minor alterations here and there.

65 This is a reference to Paradise, as mentioned in the Qur'an: "Surely the pious shall dwell amid gardens and a river, in a Seat of Truth (maq'ad șidq), in the presence of a King Omnipotent" (Qur'an 54:54-5). 
There are [also] people who realize renunciation without realizing piety. They are numerous among those who are associated with [the way of] poverty ( faqr), such as the Bahriyya and others. ${ }^{66}$ That is because they renounce this world, as there is no beneficial purpose for them in it and their hearts have no attachment to it. However, they do not realize piety and do not observe the divine commands and prohibitions. They are thus afflicted by distance [from God] and the door [to Him] is locked from them. They do not achieve any benefit with their spiritual method (sulük) due to the fact that they place a barrier between themselves and that which the Messenger (may God bless him and grant him peace) has brought. Hence, "a barrier is raised between them and that they desire!" [Qur'an 34:54].

[Piety and renunciation] are therefore the two foundations around which the spiritual way (sulük) revolves. Whoever is endowed with them, let him be given the glad tiding that the opening is near (al-fath al-qarïb), and let him prepare for the share that God will convey unto him. ${ }^{67}$ Whoever is denied that, his bargain is unsuccessful and his merchandise is without profit, /19a/ unless spiritual attraction ( $j a d h b a)$ from God comes upon a man and takes him unto Him. Yet, the way of that one should not be taken and one should not live in his vain, because it is God's constant habit (sunnat Allāh al-järiyya) ${ }^{68}$ that the

66 The word "Bahriyya" seems out of place in this context and is likely an error of the copyist. Perhaps it was meant to say "Ahmmadiyya," in which case it would most likely be a reference to the Rifāái Sufi order, named after the Iraqi Sufi Aḥmad al-Rifāīi (d. 578/1182). This would make sense, since the concept of faqr was an important part of the Rifấi way. As far as I know the word "Bahriyya" could only refer to the Baḥī Mamluks. It is certainly true that Mamluk emirs supported Sufis, whom would often be referred to as the "poor" ( fuqara $\bar{a}$, sing. faqīr), in the sense that they are in need of God. While Mamluks did offer patronage to Sufi shaykhs and brotherhoods, and sometimes joined them themselves, it is highly unlikely that they would have been linked specifically with the Sufi concept of poverty. For the Mamluks' fascination for and support of Sufi fuqarä', see for instance: Alexander D. Knysh, Ibn 'Arabi in the Later Islamic Tradition: The Making of a Polemical Image in Medieval Islam (Albany: State University of New York Press, 1999), 51.

67 A reference to the Qur'anic verse: "support from God and imminent victory" (Qur'an 61:13); in this case it appears to have a spiritual connotation and may also be translated as a "spiritual opening," which refers to God opening up the heart to knowledge of Him (ma'rifa).

68 There are several verses in the Qur'an that refer to the Sunna(s) of God: 3:137, 17:77, 18:55, 33:38, 33:61-2, 35:43, 40:85, and 48:22-3. Based on these verses, Ibn Taymiyya differentiates between two kinds: (1) those that are concerned with God's religion, which pertain to His command and prohibition, His promise and threat, etc. (2) and those that are concerned with the natural order of His creation, pertaining to the sun, the moon, the stars, and other such habits. God may suspend Sunnas of the latter kind, which, when it occurs, is 
servant travels the path [towards Him] and passes through spiritual stations (manāzil) and deserts (mafäwiz), until he arrives at his destination with experiential knowledge (márifa) of God (exalted is He). If this were not the case, then, indeed, what would be the servant's relationship to God?

It should be known that if man devoted himself to religious knowledge (al-ilm) for a hundred years or more, and if still nothing of what I have mentioned were revealed to him, he will not taste anything of the sweetness of faith (imānn) or submission (islām) with his heart. But the carnal soul (nafs) will be adorned by an abundance of religious sciences (al-ulüm) and insightful knowledge of their subtleties, for these things bring him leadership, high rank, superiority over peers and colleagues, and the fulfilment of [the carnal soul's] objectives and desires. But [his] faith will not increase by that. On the contrary, it may actually decrease due to an abundance of work for the sake of something other than God!

It ought to be known that seekers of knowledge are of three groups:

[1] A group that seeks knowledge only in order to know the legal rulings (ahkām). They do not have any objective in terms of acting in accordance with it, being morally shaped by it, or arriving unto God, the All-Knowing, by means of it (al-tawașsul bihi ilä l-alïm). They are known by love for this world and connecting with its ranks, and love for stipends (manāșib), high rank, and superiority on earth. Hence, you will see that if one of them is able to spend his soul (nafs), his wealth, or his offspring for something by which he will obtain a high rank or leadership in this world, he would do it—only in order to achieve his depraved goal. For them, that which incites them when it comes to knowledge is what they find therein of leadership and superiority on earth. God (exalted is He) said: "That is the Last Abode. We appoint it for those who desire not superiority on earth, nor corruption. The issue ultimate is to the pious" [Qur'an 28:83]. And He (exalted is He) said: "And whoso desires the tillage of this world, We shall give him of it, but in the world to come he will have no share" [Qur'an 42:20]. Among their character-traits are also arrogance, self-admiration, avarice, cowardice, and following the caprice of their carnal souls. That is because they neither shape themselves morally through religious knowledge, nor embellish themselves by putting

what human beings call a miracle (e.g. Muhammad splitting the moon, giving life to the dead, etc.). Hence, I have translated al-Ba'labakki’s use of the adjective "järiyya" here as "constant," as he is clearly referring to the first category of Sunnas, which are never suspended. Cf. Ibn Taymiyya, Jāmic al-rasā̉il, ed. Muḥammad Rashād Sālim, 2 vols. (Riyadh: Dār al-'Ațā’ li-l-Nashr wa-l-Tawzī', 2001), 1:52. 
it in practice. Rather, they belong purely to the category of the commoners ('âmmiyya). In fact, the common people have a better spiritual state $(h \bar{a} l)$ than them, because they have softer and more tender hearts. Therefore, you will see that when a commoner hears the Qur'an, a hadith of the Messenger (may God bless him and grant him peace), or stories of the righteous, his heart will become tender on account of that, he will have tears in his eyes, and he will listen to it with his entire being. But this [group], due to the excess of their arrogance and pride, and the frequency with which they repeat and hear these things without being morally shaped or learning lessons from them, cruelty gets the better of them. They thus become like someone who washes the dead without actually considering death. We ask God, the Magnificent, to not put us in this group, and to safeguard us from the evils of our carnal souls and the transgressions in our deeds, for He is the Beneficent, the Compassionate!

[2] The second group are people / $19 \mathrm{~b} /$ who seek religious knowledge in order to know by it what God (glorified is $\mathrm{He}$ ) has made incumbent upon them and then do it, what He has made unlawful to them and then abstain from it, and what he has made allowed for them and then abide by it. They are $[\ldots]^{69}$ the scholars, those who habitually practice devotion to God (ta'abbud), perform nightly prayers (tahajjud), and recite litanies (awräd) at night and day, whose hearts are committed to prayer (șalät), the remembrance of God (dhikr), and reciting the Qur'an (tilāwa). They have no strong inclination for this world, stipends, or high rank - although they are not entirely safe from that, for the human being will only be safe from love for this world and high rank by realizing renunciation. Nevertheless, they benefit from religious knowledge, knowing what is lawful (haläl), what is unlawful (harām), and what is permitted (mubāh) according to it, and what is obligatory ( fard $)$, what is necessary (wäjib), and what is commendable (sunna) according to it. They act according to their knowledge, and they teach it to the people - may God be pleased with them and make them be pleased!

[3] The third group is a people who seek knowledge in order to thereby get to know the All-Knowing (glorified is He), Who is their primary goal. Religious knowledge is the way towards intimate knowledge of Him (márifatihi), because $\mathrm{He}$ (mighty and majestic is $\mathrm{He}$ ) can only be known by means of knowledge that He Himself (glorified is $\mathrm{He}$ ) has taught them in His revealed Book and the Sunna of His Messenger (may God bless him and grant him peace), so that, consequently, they can get to know Him. When they know Him they love Him, because anyone who knows Him (glorified is He) loves Him. When they love Him they are sincere to Him, for the lover is sincere towards the one he loves.

69 There appears to be only one word here that has become illegible due to a large stain on the folio. 
They offer Him their servitude ('ubüdiyya), outwardly and inwardly, with that which His beautiful names and His exalted divine attributes require. They love what He loves and hate what He hates. The heart of none of them takes on a quality that differs from what its Beloved desires. This means that there does not arise any love in their hearts for that which He hates, nor any hate for that which He loves. They are not pleased with that which displeases Him, nor are they displeased with that which pleases Him. They do not desist from doing what He commands, nor do they rush to do what He has forbidden. This is the true meaning of conformity [to God's religion] (muwāfaqa) in every sense. Seeing this, it becomes clear that the case of love (hukm al-mahabba) is a mere claim with no truth to it. ${ }^{70}$

Now this [state of piety and renunciation combined] can only transpire by means of two things: the first of these is knowledge that teaches what God commands and what He forbids, and which acts He loves and is pleased with and which ones He hates and abhors. The second is to discipline (riya a da) and govern (siyāsa) the heart in accordance with uprightness (istiqāma) in performing all that God (mighty and majestic is He) commands, outwardly and inwardly. Whenever the heart deviates and turns towards negligence in regard to that which He commands, and inclines towards that which He hates by some passing thought (khätir) or whim (hamma), the servant must censure his heart and return it to the domain of uprightness. This will only be practiced by someone who either loves (muhibb), fears (khäif), or intimately knows [God] ('ärif), for it would be difficult for anyone else. Do you not see that the sincere servant who is dutiful towards his Master will love what He loves, hate what He hates, be pleased with what pleases Him, and displeased with what displeases Him? In the same fashion the heart of the loving knower [of God] /20a/ is molded according to the attributes of his Master (mighty and majestic is $\mathrm{He}$ ), such as generosity, clemency, compassion, patience, contentment, love for obedience and pious deeds, and hate for disobedience and offenses. Then his heart will remain naturally disposed towards conformity [to God's religion], because he has purified himself from the sources of hypocrisy and has been morally shaped by the character traits (akhläq) of the King, the Creator. 'Â'isha (may God be pleased with her) was asked about the character of the Messenger of God (may God bless him and grant him peace), and she answered: "His character was the Qur'an." ${ }^{71}$ So when [the people of this group]

\footnotetext{
70 I suspect that al-Ba labakkī means here that a mere claim to love for God in itself is not enough, but that it logically requires action in the form of conformity to His divine rulings.

71 Paraphrased from a hadith related by Muslim b. al-Ḥajjāj, al-Musnad al-șaḥịh al-mukhtașar bi-naql al-'adl 'an al-'adl ilā Rasūl Allāh (șallā Allāh 'alayhi wa-sallam), ed. Muḥammad Fu’ād 'Abd al-Bāqī, 5 vols. (Beirut: Dār Ihỵā' al-Kutub al-'Arabiyya, 1955), 1:512.
} 
assume these character traits and love their Master with all of their hearts-as [the Messenger] said in the first sermon that he preached in Medina: "love God with all of your hearts!"72 — and [when they] are sincere to Him in their servitude, outwardly and inwardly, God will reward them with His grace. It is His habit to love them, take their souls in His hand (qubdatihi), and pour out over them those lights of His might that annihilate them from all things save His beauty and greatness. What they experience is just like that which God (glorified and exalted is $\mathrm{He}$ ) put forth [in the hadith qudsī]:

My servant continues to draw near to Me with supererogatory deeds (nawäfl) until I love him. When I love him, I will be his hearing with which he hears, his sight with which he sees, and his hand with which he strikes. Indeed, if he asks me [for something] I will surely give it to him, and if he seeks my refuge I will surely place him under my protection. ${ }^{73}$

It is sufficient that I allude to their state in this spiritual station (maqām) by God's statement (glorified is He): "No soul knows what comfort is laid up for them secretly, as a recompense for that they were doing” [Qur'an 32:17].

They are the eminent ones of the Muslim community (umma) and its veracious ones (șiddīqūha $)$ who are under [God's] direct supervision. ${ }^{74}$ They are surrounded by divine gifts every day and night. They are the folk of divine contemplation (mushāhada), discourse [with God] (mukhātaba), and distinguished nearness [to Him] (al-qurb al-khāsss). They are protected [by God] when they come in sight of harshness (jaf $\vec{a})$ and are corrected whenever anything reprehensible arises from them, for God's eye guards and watches them. Divine lights do not cease to descend upon them due to the constant sight of the Lord (glorified is He) with the eye of love, friendship, pity, mercy, and protection, watching and guarding over them. Hence, they are the best

72 'Abd al-Malik b. Hishām, al-Sìra al-nabawiyya, ed. Mușțafā al-Saqqā, Ibrāhīm Abyārī and 'Abd al-Ḥafìz al-Shalabī, 2 vols. (Cairo: Maktabat wa-Maṭba'at Muștafā al-Bābī al-Ḥalibī, 1955), 1:501.

73 Muḥammad b. Ismāîl al-Bukhārī, al-Jāmi al-musnad al-șaḥịh al-mukhtașar min umūr Rasūl Allāh (șallā Allāh 'alayhi wa-sallam) wa-sunanihi wa-ayyāmihi, ed. Muhammad Zuhayr b. Nāṣir al-Nāṣir, 9 vols. (Beirut: Dār Tawq al-Najāh, 2001), 8:105.

74 "Wa-l-manzūur ilayhim kifāhan": Abū Țālib al-Makkī describes the substitutes (abdāl) with the same words in his Sufi manual, Qüt al-qulüb: "They are the seven abdāl, the pillars of the earth, who are under [God's] direct supervision," cf. Abū Țālib al-Makkī, Qūt al-qulūb fì mu'āmalat al-maḥbūb wa-wașf țarīq al-tawhìd ila maqām al-tawhīd, ed. 'Așim Ibrāhīm al-Kayyālī, 2 vols. (Beirut: Dār al-Kutub al-'Tlmiyya, 2009), 2:200. The station of the substitutes is a distinct degree of sainthood concerning which al-Balabakki cites a hadith from Ibn Hanbal's Musnad below in Risālat al-sulūk. 
after the Prophets and the Messengers, and they are their successors (khulaf $\tilde{a})$ amongst the people, among whom are those who uphold the pure religion, and those who uphold both the [outward] religion and the [inward] spiritual state $(a l-h \bar{a} l)$. It is by them that the earth is sustained, the prayer for rain is done, and the enemies are repelled. The imam Ahmad [b. Hanbal] relates [the following hadith about them] in his Musnad, saying:

\begin{abstract}
Abū l-Mughīra narrated to us_-Șafwān narrated to us—Shuraỵ̣ (i.e. ibn 'Ubayd) narrated to us, saying: The people of Greater Syria (ahl al-shäm) were mentioned in the presence of 'Alì (may God be pleased with him) while he was in Iraq. They said: 'Do curse them, O commander of the believers!' to which he replied: 'Verily, I have heard the Messenger of God (may God bless him and grant him peace) say: "The substitutes (abdāl) /20b/ will be in Syria and they are forty men. Whenever one [of them] passes away, God replaces him with another man. It is by them that the rain comes down, it is by them that you triumph over the enemies, and it is by them that [God's] punishment is kept away from the people of Greater Syria!"'75
\end{abstract}

May God place us among them, lead us on their path, and gather us with them [on the Day of Judgment], for He is the most Merciful of the merciful!

Know that seeking this world and striving for its sake are amongst the most loathsome things there are. The one who seeks it will remain in [a state of] exertion, hardship, distress, vileness, and humiliation, for he has no worthneither to God nor to the people! Among them is one whose service is frequently sought by those who are unjust, their helpers, or others in whom no sound faith ('aqìda șäliḥa) exists, in order to aid him in his worldly life and fulfil his needs. That way, they subjugate and degrade him under the assumption that they devote themselves to him and honor him. This is the greatest temptation for him and the furthest away from God (exalted is He), for these [people] become the idol of his heart! Whenever a mishap occurs to him or a severe calamity befalls him, his heart turns to them to fulfil his need and remove his calamity. Does it befit someone who has the slightest whiff of faith (ìmān) and submission (islām) to serve His Lord while he subjugates his heart to something other than Him and relies [on that] to fulfil his needs and remove his calamities, [all the while it is God] Who created him, nourished him, subjected to him all that is in the heavens and the earth, is responsible for his provision,

75 Aḥmad b. Ḥanbal, Musnad al-imām Ahmmad b. Hanbal, ed. Shu'ayb al-Arna'ūt, 'Ādil Murshid, et al., 45 vols. (Beirut: Mu’assasat al-Risāla, 2001), 2:231. 
and Who is called upon every night to fulfil his needs?! ${ }^{76}$ Truly, by Him besides Whom there is no other deity, if he is sponsored by one of the emirs, or anyone else upon whom he relies for his provision or to fulfill his needs, his heart is tranquil, his passing thoughts are settled, his carnal soul is happy, and his anxieties relieved!

When it comes to this [reliance on other than God], O my beloved one, this is only caused by distance (bu'd) from God (mighty and majestic is $\mathrm{He}$ ) and the absence of certainty about that which God (glorified is He) is responsible for. ${ }^{77}$ All of these things only come to someone who consents to be without renunciation. It should be known that "love for this world is the root of every sin," 78 for it thereby comes to pass that people envy and hate each other, sever their relations, and treat one another with enmity. From it rises leadership, arrogance, pride, and vanity, and from it stem deeds that are done so that others may see or hear about them (al-riya $\vec{a}^{\prime} w a-l-$ sum $\left.^{\prime} a\right)$, because the insincere will either show off for the sake of this world or for the sake of leadership and reputation. The renunciant (zähid) is free from all of these afflictions, and he is beloved to God and to the people, as [the Messenger] (may God bless him and grant him peace) said: "Renounce that which people have and they will love you, and renounce this world and God will love you." ${ }^{79}$ It is hoped for someone who possesses the quality of renunciation that God (glorified and exalted is $\mathrm{He}$ ) will take him unto Himself by the grace of His love for him.

If man reflects upon the Book and the Sunna, he would find them filled with renunciation [of this world], /21a/ such as [God's] statement (exalted is He): "Let not the present life delude you, and let not the Deluder delude you concerning God" [Qur'an 31:33 \& 35:5], and in more than one place in the Qur'an. Were it not for the fact that our words here would become lengthy, we would have mentioned many [more] quotations from the Book and the Sunna.

It is thus necessary that man reflects upon the Qur'an when he reads it and be shaped morally by it, in the same way as the Messenger (may God bless him and grant him peace) did, and that he strives to attain a relationship (nisba)

76 References to Qur'anic verses, such as 14:32, 14:33, 16:12, 16:14, 22:36, 31:20.

77 A reference to al-Ba'labakkī's words in the previous paragraph, where he states that God takes responsibility to provides man with sustenance $(r i z q)$. This is mentioned in the Qur'an several times; for instance: “... and not to slay your children because of poverty; We will provide you and them" (Q 6:151), "Surely God is the All-Provider (al-Razzāq)..." (Q 51:58), "No creature is there crawling on the earth, but its provision (rizq) rests on God" (Qur'an 11:6).

78 Abū Bakr 'Abd Allāh b. Abī al-Dunyā, al-Zuhd, (Damascus: Dār Ibn Kathīr, 1999), 26.

79 Muhammad b. Mājah, Sunan Ibn Mãjah, ed. Shu'ayb al-Arna’ūṭ, 'Ādil Murshid, et al., 5 vols. (Beirut: Dār al-Risāla al-'̄alamiyya, 2009), 5:225. 
that connects him unto God (mighty and majestic is He) (tajma'uhu 'alä llāh). For when man is on the verge of death, all of the worldly attachments and distractions that used to occupy him leave him, and his heart is solely concerned with all that comes upon him of this great affair. A person will then be destitute, having nothing with him! It may be that [at that moment] doubts and suspicions face him, and it may be that he deviates from [professing God's] divine unity (tawhid) altogether, because he is destitute and Satan prevails [over him], and it may be that [Satan] deceives him and seduces him away from the religion. This is contrary to the one who has attained the divine relationship, whose heart is connected to God (mighty and majestic is He), for this relationship is stronger than anything that may happen when mishaps occur. Do you not see that he who is connected to a king or someone of high standing, that when a calamity befalls him, his heart is strengthened by his master and he pays it no heed, since he knows that [his master] will aid him and deliver him from that calamity? The same goes for the one who has attained a relationship with God (glorified is He): it is hoped that his faith becomes stronger at the trial of death, due to his heart's connection (ittișa $\bar{l}$ ) with God (mighty and majestic is He), for God will honor him and have mercy on him, and He will neither neglect him nor forsake him at the moment when he will need Him the most. So, such a man will die and be resurrected with this connection-if God (exalted is He) wills it so! The Messenger of God (may God bless him and grant him peace) said: "The intelligent one is he who subjugates his carnal soul and strives for what follows after death, and the one lacking in intelligence is he who follows the caprice of his carnal soul that desires from God [what it longs for]." ${ }^{\circ 0}$

We ask God the Magnificent to strengthen us in Islam and the Sunna, that He resurrects us accordingly, and that He gathers us with the Prophets, the veracious, the martyrs, and the righteous upon whom he has given his blessings - for He is the Beneficent, the Compassionate! This [epistle] has come to completion, so praise be to God alone, and may His blessings and peace be upon our Master Muhammad, the best of His creation, and upon his family and companions!

8o The ms omits the word "al-amānī", which is found in the version of the hadith related by al-Tirmidhì. Since it makes more sense in the translation, it has been rendered between brackets here. For the hadith, see: Muḥammad Abū 'Īsā al-Tirmidhī, Sunan al-Tirmidhī, ed. Aḥmad Muhammad Shākir, Muḥammad Fu’ād 'Abd al-Bāqī, and Ibrāhīm 'Uțwa, 5 vols. (Cairo: Maktabat Muștafāa al-Bābī al-Ḥalabī, 1975), 4:638. 